\title{
Future accessibility impacts of transport policy scenarios: equity and sensitivity to travel time thresholds for Bus Rapid Transit expansion in Rio de Janeiro
}

\author{
Rafael H. M. Pereira \\ Transport Studies Unit (TSU) - Oxford University, UK \\ Institute for Applied Economic Research - Ipea, Brazil
}

\section{Highlights}

- The study estimates how the TransBrasil BRT project in Rio de Janeiro will likely impact employment accessibility for different income groups

- The full implementation of the proposed BRT could benefit up to 58\% of the city population, increasing job accessibility by $11 \%$ on average

- This BRT project could promote substantially larger accessibility gains for lower-income groups and reduce inequalities in access to opportunities

- The study shows that the conclusions of equity assessments of transport projects depend on the travel time threshold chosen for cumulative opportunity accessibility analysis

\begin{abstract}
The accessibility impacts of transport projects ex-post implementation are generally evaluated using cumulative opportunity measures based on a single travel time threshold. Fewer studies have explored how accessibility appraisal of transport plans can be used to evaluate policy scenarios and their impacts for different social groups or examined whether the results of project appraisals are sensitive to the time threshold of choice. This paper analyzes how different scenarios of full and partial implementation of the TransBrasil BRT project in Rio de Janeiro (Brazil) will likely impact the number of jobs accessible to the population of different income levels. The analysis is conducted under various travel time thresholds of 30, 60, 90 and 120 minutes to test whether the results are sensitive to the boundary effect of the modifiable temporal unit problem (MTUP). Compared to a partial operation scenario, the full implementation of TransBrasil that extends this corridor into the city center would lead to higher accessibility gains due to network effects of connecting this BRT to other transport modes. Nonetheless, the size of the accessibility impacts of the proposed BRT as well as its distribution across income classes would significantly change depending on the time threshold chosen for the accessibility analysis. Considering cut-off times of 30 or 60 minutes, both scenarios of TransBrasil would lead to higher accessibility impacts in general and particularly for low-income groups, moving Rio towards a more equitable transportation system. However, under longer thresholds of 90 and 120 minutes, an evaluation of this project would find much smaller accessibility gains more evenly distributed by income levels. The paper highlights how time threshold choice in cumulative opportunity measures can have important but overlooked implications for policy evaluation and it calls for further research on the MTUP in future transport and mobility studies.
\end{abstract}

Keywords: Equity, Accessibility, BRT, Rio de Janeiro, Distributive justice, Transport policy, Scenario, MTUP 


\section{Introduction}

Over the past decade, there has been growing concern over the equity impacts of public transport investments (Ciommo \& Shiftan, 2017; Lucas, 2012), particularly of Bus Rapid Transit (BRT) projects, which are increasingly being adopted worldwide (Delmelle \& Casas, 2012; Venter et al., 2017). This is largely reflected in the growing number of academic studies and transport agency reports assessing how projects impact local communities and particularly vulnerable groups in terms of their access to out-of-home activities, such as employment and educational opportunities (Karner \& Niemeier, 2013; Manaugh et al., 2015). Most of these studies measure accessibility levels using cumulative opportunity measures of accessibility (Boisjoly \& ElGeneidy, 2017; Papa et al., 2015), which allow estimating, for example, the number of jobs accessible to a population group under an ad-hoc travel time threshold of say 60 minutes (Geurs $\&$ van Wee, 2004). As a rule, however, these studies only consider a single cutoff time value and have thus far overlooked whether the conclusions/results are sensitive to different travel time thresholds. This issue is directly related to the modifiable temporal unit problem (MTUP) (Cheng \& Adepeju, 2014), which has been largely overlooked in the transportation literature (see section 2).

Moreover, most of these studies focus on the ex-post assessment of the accessibility impacts of transport investments, i.e. after the projects are implemented. Nonetheless, there is a growing need to understand how researchers and policymakers can estimate the likely accessibility impacts of transport plans before they are implemented and evaluate how their accessibility gains are distributed across different social groups (Guthrie et al., 2017; van Wee \& Geurs, 2011). The dearth of this kind of evaluation is particularly significant in developing countries, where the accessibility and equity impacts of transport plans are often overlooked by local authorities (Blanco et al., 2018; Vasconcellos, 2001, 2014) and where the challenges of transportation are likely to grow due to rapid urbanization under conditions of inadequate transport infrastructure (UN-HABITAT, 2010).

The aim of this paper is twofold. First, it examines a major BRT project in a developing country to illustrate how future scenario analysis can be used to anticipate the likely accessibility impacts of transport plans for different income groups across space; second, it investigates whether the conclusions of the equity analysis of transport projects are robust when using 
cumulative opportunity measure of accessibility based on different travel time thresholds. The study analyzes the TransBrasil project in Rio de Janeiro (Brazil), a 32-km long BRT corridor that was planned alongside other major public transport investments in preparation for the 2016 Olympic Games. Despite its strategic role in integrating Rio's public transport system and connecting high-density low-income neighborhoods to the city center, the TransBrasil BRT remains unfinished because of legal disputes and fiscal issues. Only a part of the project is currently under construction and a fiscal crisis that recently hit the local government has raised serious uncertainties about whether this BRT is ever going to be finished (see section 3).

This paper estimates the likely future impacts of the TransBrasil corridor on the number of jobs accessible to the population via public transport, measuring how accessibility gains vary across space and income classes and to what extent these are affected by the choice of travel time threshold (30, 60, 90 and 120 minutes from door to door). Combining population census and land use data with geolocated timetables of Rio's public transport network, the paper assesses how two scenarios of the BRT plan - full and partial implementation of the project - will increase the number of formal jobs that people from different income levels and areas of the city can reach from their homes via public transport and walking. The study investigates how accessibility gains brought by the proposed BRT project will be distributed across income groups and whether the results are robust to boundary effect of MTUP (see section 3). A spatial regression model was also used to provide a more robust analysis of the results and it is presented in a Statistical Annex.

The remainder of this paper is organized as follows: the next section presents a short review of the literature on transportation equity and accessibility. Section three presents the study area of Rio de Janeiro and its unfinished BRT project. Data and methods are presented in section four and results presented in section five. Section six presents the conclusions.

\section{Transportation equity and accessibility}

There is extensive literature on how transport investments can reshape people's access to out-ofhome activities and improve wellbeing (Banister \& Hickman, 2006; Lucas, 2012). Previous studies have conducted accessibility analysis to examine how people's access to jobs by car or public transport can be affected by future transport and land-use scenarios (Anderson et al., 
2013; Geurs \& va Eck, 2003; Tilahun \& Fan, 2014). Some studies have also focused specifically on different scenarios of alternative public transport projects, looking at their accessibility impacts across racial/ethnic and income groups (El-Geneidy et al., 2011; Farber \& Grandez, 2017; Manaugh \& El-Geneidy, 2012; Niehaus et al., 2016). In recent decades, transport authorities, mainly in European and North American cities, have started using this type of accessibility analysis to evaluate their policies (Boisjoly \& El-Geneidy, 2017; Papa et al., 2015) with particular concerns regarding the different social impacts of their projects on population groups (Karner \& Niemeier, 2013; Manaugh et al., 2015).

While there is no consensus among transport authorities or academics about what makes a transport investment equitable, an egalitarian-prioritarian view of justice like the one developed by John Rawls $(1999,2001)$ is increasingly influential among academics (Lucas et al., 2015; Martens, 2012; Pereira, Schwanen, et al., 2017; van Wee \& Roeser, 2013) and official transport authorities (Karner \& Niemeier, 2013; Manaugh et al., 2015). According to this view, a 'fair' transport policy prioritizes improving the accessibility conditions of people from disadvantaged groups. These include various social groups whose capabilities to use a transport system to access out-of-home activities and participate in society (or develop a fulfilling life) are systematically undermined by morally arbitrary factors such as being born in a poor family, having a disability, or belonging to a particular gender or racial/ethnic category (Pereira, Schwanen, et al., 2017).

There are various methods of measuring accessibility to discuss equity impacts of transport policies (Martens \& Golub, 2012; Neutens et al., 2010; van Wee \& Geurs, 2011). Cumulative opportunity measures are among the most commonly used among academic researchers (Fan et al., 2012; Golub \& Martens, 2014; Manaugh \& El-Geneidy, 2012), funding agencies (Scholl et al., 2016) and transport agencies (Boisjoly \& El-Geneidy, 2017) to analyze the accessibility and social impacts of transportation investments. Some advantages of this type of accessibility measure are that it does not require prior information about people's travel behavior, is computationally inexpensive and produces results that are easy to communicate to policymakers and stakeholders. This makes it a particularly attractive measure to inform decision-making. It also has limitations, however, since it assumes that all opportunities are equally desirable, regardless of the time spent traveling; it does not take competition effects into account; it accounts neither for the space-time constraints on people activity-travel behavior nor 
the possibility of trip-chaining; and it involves the selection of an arbitrary cutoff travel time (Geurs \& van Wee, 2004; Neutens et al., 2010). Another known limitation of cumulative opportunity metrics of accessibility is that they involve the selection of an arbitrary cutoff travel time, but the implications of this shortcoming for the appraisal of transport projects has been overlooked in the literature thus far.

\section{Modifiable Temporal Unit Problem (MTUP)}

As a rule, researchers and practitioners evaluate the accessibility impacts of transport investments and devise policy recommendations based on accessibility analyses that consider a single cutoff time value (e.g. Boisjoly \& El-Geneidy, 2016; Fan et al., 2012; Golub \& Martens, 2014; Manaugh \& El-Geneidy, 2012). By doing this, these studies disregard how the evaluation of transport projects and subsequent policy recommendations could vary depending on an ad-hoc choice of time thresholds. This issue relates to the boundary effect in the modifiable temporal unit problem (MTUP) (Cheng \& Adepeju, 2014; Huang \& Wong, 2015), which is the temporal analog of the modifiable areal unit problem (MAUP). The MAUP effect has been extensively explored in the geographical literature (Apparicio et al., 2008; Tan \& Samsudin, 2017) and it draws attention to how the conclusions of spatial analysis are often sensitive to the ad-hoc ways in which spatial data are aggregated according to different geographical scales and zonal schemes. Various studies have examined how transport accessibility estimates can be sensitive to the MAUP (Kwan \& Weber, 2008; Omer, 2006; Ortega et al., 2012; Pereira, Banister, et al., 2017; Zhang \& Kukadia, 2005). Nonetheless, the literature has generally overlooked the effects of MTUP and whether the arbitrary choice of cutoff time values has any influence on estimates of accessibility inequalities and on the equity assessment of transport projects.

The MTUP is one manifestation of a broader issue of frame dependence in geographical analysis (Kwan, 2018). The MTUP refers more specifically to how the results of a given analysis can be affected by how the data are organized with respect to its temporal dimension. One of the first studies to systematically articulate the MTUP is a paper by Cheng and Adepeju (2014), who proposes that MTUP consists of three components: aggregation, segmentation and boundary.

Temporal aggregation is a process of grouping data points in a temporal window. When estimating the cumulative accessibility level at a given location, for example, there will be a 
different accessibility point estimate depending on when a person departs relative to when a public transport vehicle arrives, and how well transfers are coordinated given a service timetable. To take this variation into account, some studies consider the average or mean accessibility level across a sample of various departure times during a certain time interval (Fan et al., 2012; Owen \& Levinson, 2015; Pereira, Banister, et al., 2017). The MTUP aggregation effect relates to scale or the size of the time window used to aggregate the data, which could be a one-hour period or a three-hour period for example. A related aspect refers to sample size in terms of the number of departure times considered, which gives higher or lower frequency/resolution to the data analysis. Conway et al (2018) propose new methods to estimate probabilistic accessibility levels that account for uncertainties in service schedules and which could possibly help address the MTUP aggregation effect in future research. The aggregation effect is out of the scope of this study.

The segmentation effect relates to the selection of the starting point of that time window. In the previous example, this could mean calculating average accessibility for a sample of departure times over a period between 7am-9am during peak time, or between 9pm-11pm during off-peak hours. Previous studies have demonstrated how the selection of this starting time influences accessibility estimates because of the variation in service levels across the day (Fan et al., 2012; Farber et al., 2014) and in different days of the week (Neutens et al., 2012). Although these studies do not explicitly articulate the MTUP, they demonstrate how the segmentation choice can have important equity effects. The segmentation effect is not addressed in this study because of the lack of information on how the TransBrasil BRT will operate in off peak hours and in the weekends

Finally, the third effect of MTUP is the boundary effect, which relates to the temporal length of a space-time process. In the example of calculating a cumulative opportunity accessibility measure at a given location, this effect refers to selection of the maximum temporal extent or duration of the trip. As a rule, previous studies analyzed transport accessibility using a single travel time threshold that commonly varies between 30 and 60 minutes (Boisjoly \& ElGeneidy, 2017; Papa et al., 2015). One exception is the study of Palmateer et al. (2016), who analyzed the accessibility impacts of an arterial bus rapid transit service in Minneapolis-Saint Paul (USA) under cutoff time values of 10, 20, 30, 40, 50 and 60 minutes. The authors found that average accessibility benefits gradually increase up to thresholds between 30 and 40 minutes and 
then decline, what reflect the extent of the geographical and temporal influence of the transport project analyzed. The present study advances previous research by investigating whether and to what extent the boundary effect of MTUP can influence the evaluation of the accessibility impacts of transport projects and its distributional effects across income groups.

\section{Study area: Rio de Janeiro}

The city of Rio Janeiro has approximately 6 million inhabitants, just over half of the population residing in its metropolitan region. Like many other cities in the Global South, Rio is the result of decades of rapid population growth and fragmented urban development (UN-HABITAT, 2010). This gave rise to a city with high levels of urban segregation (Ribeiro et al., 2010), uneven provision of infrastructure (Câmara \& Banister, 1993; Ribeiro, 2014) and poor transport conditions (Motte-Baumvol et al., 2016; Pereira \& Schwanen, 2013).

Since the late 1990s, local authorities have incorporated into the city's urban plans the goal of making Rio a stage for international mega-events, having successfully hosted the 2007 Pan American Games, 2014 FIFA World Cup and 2016 Olympic Games (Gaffney, 2010; Kassens-Noor et al., 2016). This event-led planning agenda has triggered substantial investments in the city's transport system, particularly between 2012 and 2017, including a subway extension, a light rail system in the city center and four new BRT corridors (Figure 1). These transport investments were promoted as one of the main legacies of recent sports mega-events. According to local authorities, the new transport projects would collectively help the city overcome its socially fragmented urban development and reduce commute times, particularly to and from the poorest marginalized neighborhoods (Brazil, 2009). According to data of the 2013 household travel survey of Rio, commute trips by public transport and walking within the city used to take 57 minutes on average.

The TransBrasil BRT (red line in Figure 1) is perhaps one of the most important pieces of infrastructure amid this promised transport legacy of mega-events in Rio. At a cost of approximately US\$500 million, the project has 26 stations and length of $32 \mathrm{~km}$, running from the city center where most of the employment opportunities are concentrated to one of the most densely populated regions with lowest income levels in the city. It was proposed with a crucial role of integrating the city's public transport network. The TransBrasil corridor is planned to 
have two terminals where it integrates with city and metropolitan bus lines, and it should have integrated stations with the Transolímpica BRT as well as the commuter rail and subway systems. According to official estimates, TransBrasil is expected to be the BRT corridor with the highest demand in the city, carrying 800 thousand passengers per day (Logit, 2014).

Figure 1. Medium and large capacity transport corridors. Rio de Janeiro, 2017.

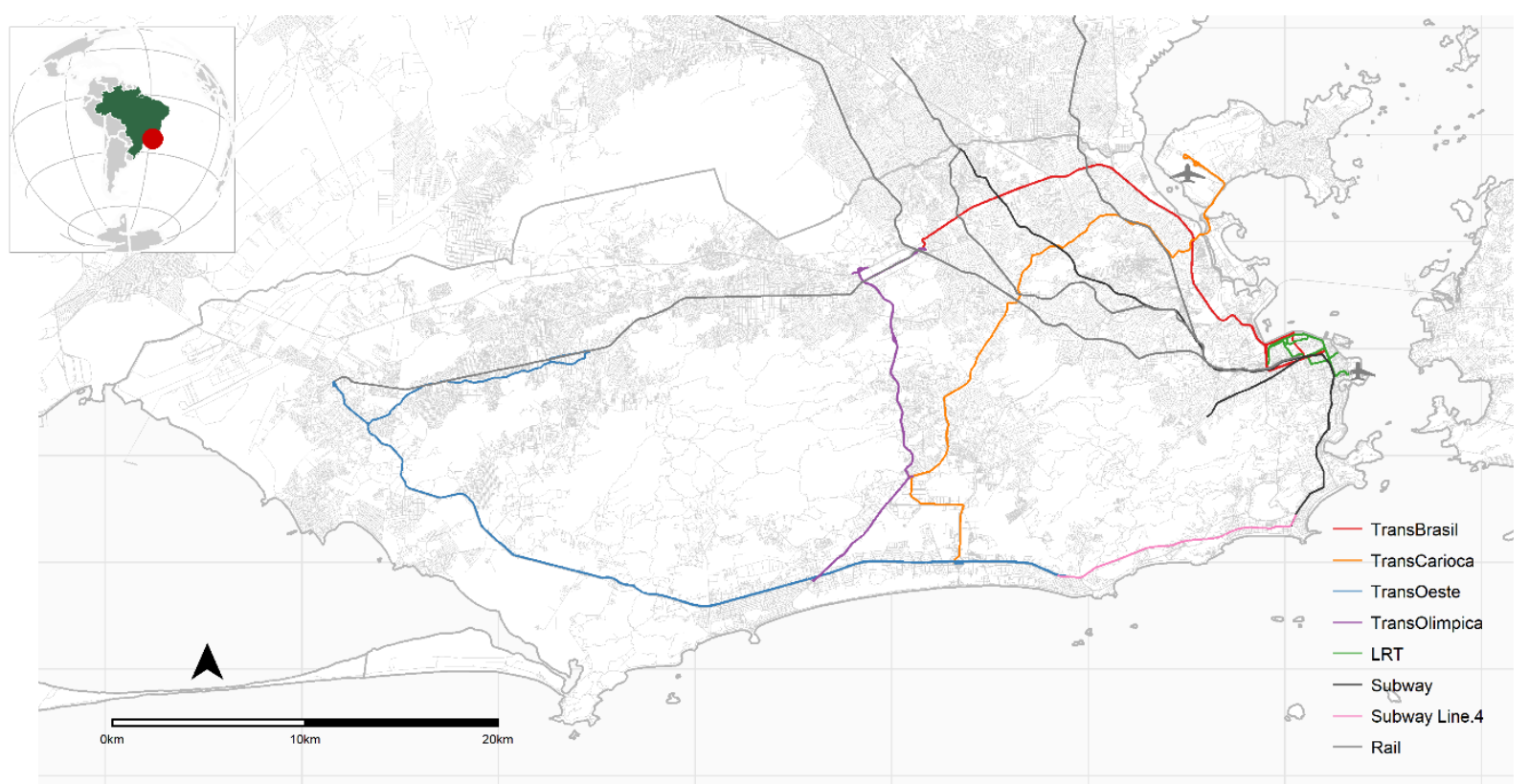

However, while all the other mega-event related investments in Rio's transport network were fully or partially operational before the 2016 Olympic Games, the TransBrasil BRT remains unfinished (2018). The construction work on TransBrasil was suspended for over nine months between 2016 and 2017 because of legal disputes with construction companies. Although contractors have restarted building a section of the project (between Deodoro and Caju stations Figure 2), there is no perspective for when this section is going to be finished. Local authorities have recognized there is even greater uncertainty whether the full project (reaching downtown) will ever become fully operational (Candida, 2017; Lisboa, 2017), and this would create a first/last-mile problem for people moving in and out of the city center (Givoni, 2016). Moreover, the city of Rio has been hit by a severe economic crisis since 2016, which has led to a $70 \%$ cut in the municipal transport agency's budget (Magalhães \& Rodrigues, 2017) and a significant drop in passenger demand due to rising unemployment rates (França, 2016; Rodrigues, 2017). 
Because of this situation, various bus companies claim they are facing a difficult fiscal situation. Indeed, seven companies went bankrupt between 2015 and 2017 and 12 others are threatening to do so, which could affect feeder lines and undermine people's access to the BRT services (Zarur, 2017; Zuazo et al., 2017).

There is a high level of uncertainty about whether the TransBrasil corridor will be completed. A prospective study that assesses the likely accessibility impacts of this BRT can offer additional information about the relevance of this project to the city's transport system. To the best of my knowledge, however, no study has thus far estimated the accessibility benefits of TransBrasil or its differential effects for various income groups. From a transportation equity point of view, it is very important to understand who will ripe the accessibility benefits of this BRT project funded by the government, and whether the answer to this question is robust to time threshold choice in the accessibility analysis. The next section describes the data and methods used to address these questions.

Figure 2. Detail of the TransBrasil BRT corridor. Rio de Janeiro, 2017.

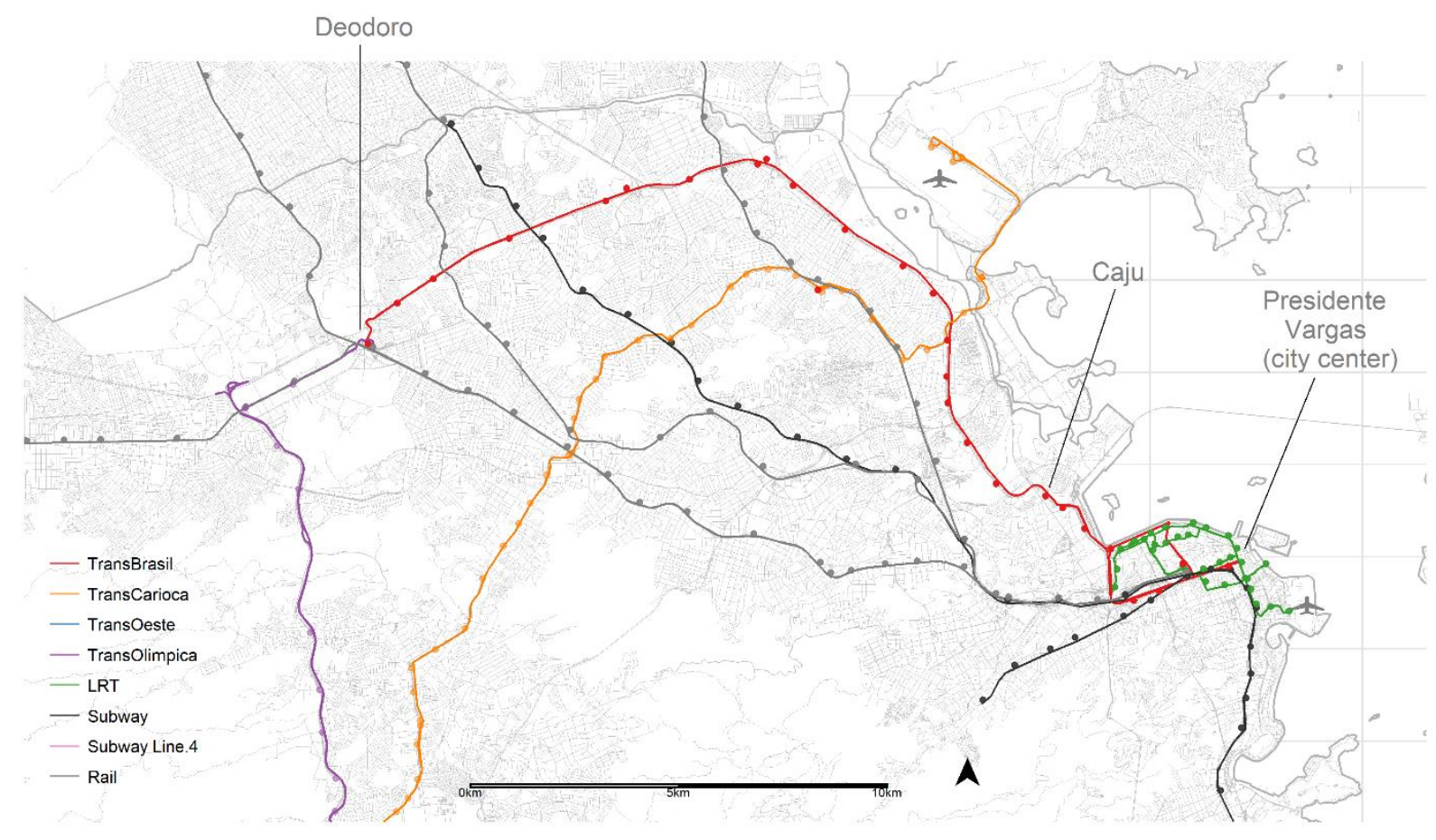

Note: As of the writing of this paper, the BRT section between Deodoro and Caju stations is under construction and expected to be completed by October 2018 (RJTV, 2018). Local authorities have not given any estimate of when construction work of the section between Caju and Presidente Vargas will start. 


\section{Methodology}

A cumulative opportunity measure is used to estimate the likely impact of the TransBrasil BRT project on the number of formal jobs accessible by the population of different income levels via public transport and walking within various time-thresholds. Accessibility levels are estimated under a business-as-usual baseline without the TransBrasil corridor and then compared to two scenarios of partial and full operation of the BRT. The data sources and methods used in this study as detailed below.

\subsection{Data Sources}

Population count data comes from the 2010 Brazilian Census (IBGE, 2016) and were organized in a hexagonal grid of 500 by 500 meters with 5,520 cells. The choice of 500 meters allows a high-resolution accessibility analysis without compromising computational tractability. A hexagon grid was used to reduce sampling bias from edge effects and because it is more suitable than rectangular grid to analyze spatial phenomena in which nearest neighborhood and connectivity are important (Birch et al., 2007). The resident population in each grid cell was categorized according to income decile based on the average household income per capita of each grid cell. This was imputed from census data organized into 1,136 relatively homogeneous socioeconomic polygons known as Human Development Units (Ipea et al., 2015). The data on household income per capita collected in the census account for all members of the household and all their sources of income (including formal and informal jobs, unemployment benefits, pensions, social transfers, etc.). Although the census has some limitations in terms of capturing the upper extreme of income distribution (Souza, 2015), it is still the best data source to account for income distribution in Brazil. These data on income needs to be used with caution because it incurs ecological fallacies by disregarding socioeconomic heterogeneity within Human Development Units.

Data on formal jobs come from RAIS, a national register organized by the Ministry of Labor and Employment that has full addresses of all public and private establishments and the socioeconomic characteristics of their employees working in the formal labor market - i.e. with a formal labor contract and social security contributions. In 2015, there were 2,914,238 formal 
workers employed in 227,362 establishments in Rio. In this database, workers are associated with the address of their respective workplaces. Exceptionally, some institutions with multiple offices/branches (such as outsourcing firms or public entities - police, health and education) report all their employees to be working from the institutional headquarters. Among the 50 largest employers in Rio, 17 entities were found to do this and were removed from the analysis. The location of 83,589 employees working for the municipal education secretariat could be recovered from the school census. In the end, a database covering $92.3 \%$ of all formal workers in the city was used. This procedure should not substantially change the results of this study because the jobs excluded from the database are distributed in different locations in Rio and correspond to only a small fraction of formal jobs in the city.

Due to the unavailability of a data source with the addresses of jobs in the informal labor market, this study does not consider informal jobs. Although a significant share of workers in Rio self-declared to work in the informal labor market (approximately 36\% in January $2016{ }^{1}$ ), the 2003 household travel survey of Rio shows that the numbers of formal and informal jobs in each traffic zone are correlated at 0.78 (Pearson correlation, statistically significant at 0.001). This suggests that the spatial distribution of formal and informal jobs in the city is not radically different, so that the lack of data on informal jobs should not radically change the relative distribution of accessibility estimates using cumulative opportunity measures.

Spatial information on road network and pedestrian infrastructure comes from OpenStreetMap. Finally, data on the public transport network was provided by Fetranspor (Federation of Passenger Transport Companies in Rio de Janeiro). The dataset is organized in General Transit Feed Specification (GTFS) format and it provides a snapshot of the scheduled services for May 2017, with detailed geolocated information of routes, stops and timetables of the public transport system.

\subsection{Simulating the TransBrasil BRT project}

In order to analyze the future accessibility impacts of the TransBrasil corridor, a GTFS data feed representing the scheduled services of this BRT was created using the official data presented in

\footnotetext{
${ }^{1}$ Source: National Household Sample Survey (PNAD/IBGE), available at http://www.ipeadata.gov.br/ .
} 
the latest revised operational plan of the project (Logit, 2014). According to this plan, 12 services would run in the TransBrasil corridor and 7 services would run between the TransBrasil and Transcarioca BRT corridors, including both regular routes that stop at various stations and express routes that only stop at a few stations. The sequence of stops in each of these services is presented in Appendix I. In the accessibility analysis, the full operation scenario considered all stops in Appendix I, while the partial operation scenario only considered the stops between Deodoro and Caju stations, which is the section of the project currently under construction. The plan also presents some operational characteristics of these services during the morning peak time, including total length, travel time, average speed, frequency and headways. The plan of the project, however, only brings information on service levels during peak time, what prevented estimating accessibility during off-peak hours including the night-time period. These characteristics were also used to create a GTFS representation of the project and they are summarized in Appendix II.

Following this 2014 revised plan of TransBrasil (Logit, 2014), eight regular bus routes would have significant overlap with the new BRT and the intention was to cease their operation. Five of these routes were still present in GTFS files of May 2017 and removed from the analysis in this study. Moreover, the plan also identified 77 regular bus routes in the city of Rio to have partial overlap with the proposed BRT, recommending these routes to be shortened and turned into feeder lines. The document, however, does not provide enough information on how these routes should be modified, so they were kept unchanged for the purpose of this study. This means that the final GTFS dataset used still presents partial overlap between TransBrasil BRT and existing bus routes, which may have resulted in inflated accessibility estimates. This limitation deserves more attention and is discussed in the results section.

\subsection{Accessibility analysis}

Accessibility levels have been estimated using a cumulative opportunity measure that indicates the number of formal jobs accessible by the population of different income levels via public transport and walking under a certain cutoff travel time. This type of accessibility measure requires setting a travel time threshold. There is however no consensus on how a sensible threshold should be selected. While the average commute time of the area under study is a good 
reference, average measures conceal important variations in the data. In the case of the city of Rio, $46 \%$ of the population has a commute longer than the average of 57 minutes, and close to $20 \%$ of the population commutes longer than 90 minutes. It is also reasonable to assume that the selection of an appropriate time threshold should consider the type and size of the transport project, for example if it is a subway or a light-rail and the extension of the project. Or one could argue that such appropriate threshold should be defined based on a normative idea of what a maximum acceptable commute time should be. In summary, the selection of a sensible cut-off travel time is context-specific, and it is not as straightforward as it seems. A legitimate concern here is to prevent advocates of a certain position from opportunistically choosing the results that support their arguments. The analysis in the paper is conducted using various travel time thresholds (30, 60, 90 and 120 minutes) for the sake of sensitivity analysis and it does not claim that all of these thresholds are equally appropriate for this case-study.

The study estimates the number of jobs accessible from every hexagonal grid cell of 500 meters via public transport and walking. OpenTripPlanner ${ }^{2}$ was used to estimate travel time matrices by public transport and/or walking between every pair of centroids of hexagonal cells. Population-weighted centroids of each polygon have been used as origins and destinations in order to minimize aggregation errors (Stępniak \& Jacobs-Crisioni, 2017). The study of Boisjoly \& El-Geneidy (2016) has found that accessibility levels measured at 8am are representative of the relative accessibility at other time periods the day in Toronto. In this paper, though, various travel time matrices have been calculated for a typical business day, departing every 15 minutes between 7 a.m. and 9 a.m. in order to take into account possible variations in accessibility due to temporal variations in service levels and departure times. These travel time matrices contain door-to-door estimates that consider walking time from the point of origin to the public transport stop, waiting time for the vehicle, actual travel time through the transport network, waiting time during transfers, and the walking time from the transport stop to the final destination.

These travel time matrices have been combined with the geolocated data on population and jobs. Based on equation (1), the median number of jobs that can be accessed from each grid cell via public transport and walking across the various travel time matrices have been calculated for the business-as-usual baseline and for both partial and full operation scenarios. In an attempt

\footnotetext{
${ }^{2}$ OpenTripPlanner is an open-source multimodal trip planner available at https://github.com/opentripplanner/OpenTripPlanner.
} 
to reduce qualitative mismatch between workers' socioeconomic position and job positions, job accessibility levels were adjusted on the basis of household income per grid cell and educational qualifications of jobs. For residents in grid cells above the 5th income decile, accessibility estimates only considered employment opportunities that required high or secondary education, while for grid cells below the 5th income decile only jobs that required secondary or primary education were considered. This assumption needs to be taken with caution because it incurs in ecological fallacy since it assumes all individuals in the same grid cell will to have the same income level. The conclusions of the paper remained the same when the empirical analysis was conducted disregarding the qualitative match between workers' income level and educational qualification of jobs positions.

Where:

$$
\begin{aligned}
& A_{o, i, T}=\operatorname{median}\left(\sum_{o=1}^{n} P_{d} f\left(t_{o d r}\right)\right) \\
& f\left(t_{o d r}\right)=\left\{\begin{array}{l}
1 \text { if } t_{o d r} \leq T \\
0 \text { if } t_{o d r}>T
\end{array}\right.
\end{aligned}
$$

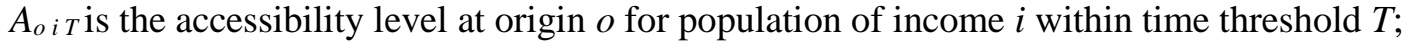

$P_{d}$ is the number of formal jobs in location $d$;

$t_{o d r}$ is the travel time in minutes between origin $o$ and destination $d$ at departure time r; and

$f\left(t_{o d r}\right)$ is a time threshold function that varies between one and zero, depending on whether travel time ( $t_{o d}$ $r$ ) is longer or shorter than time threshold $T$.

Previous studies have shown that people's ability to use public transportation and hence their accessibility levels are dependent on affordability (El-Geneidy et al., 2016), disability (Casas, 2007), age (Ryan et al., 2015) or gender (Akyelken, 2017). The accessibility analysis conducted in this study did not consider these issues due to data availability constraints and is thus likely to underestimate accessibility inequalities (Neutens et al., 2010). Another limitation of this analysis is that is does not consider the long-term effect that the new BRT project might have on the relocation of job opportunities and population. Such land-use impacts of a transportation investment are difficult to model and take time to materialize. If the accessibility gains brought about by construction of TransBrasil attract more jobs to locate closer to the BRT stations, it is likely that the results of this study will underestimate the long-term accessibility benefits of this proposed BRT corridor. Because this paper seeks to isolate the short-term impact of the BRT project on accessibility levels, data on the spatial distribution of jobs and population 
have been kept constant in the analysis. Moreover, previous studies have shown that the spatial distribution of jobs in socioeconomic groups has remained fairly stable over the past two decades in Rio (Lago, 2000; Ribeiro, 2014).

\section{Results}

Constructing the TransBrasil project either partially or in full will generate moderate to substantial average gains in accessibility, although the magnitude of these gains and the number of people who benefits from them differs depending on the travel time threshold selected for the accessibility analysis. Table 1 below summarizes the impact the TransBrasil BRT could have on people's access to employment opportunities under various time thresholds. These results suggest, for example, that the full construction of this BRT could benefit approximately 800 thousand people (13.7\% of Rio's population), with an average increase of $13.3 \%$ in job accessibility under a travel time of 30 minutes. Under 60 minutes, 3.6 million people $(58.5 \%$ of the city's population) would be able to reach on average $11.3 \%$ more jobs under the fullconstruction scenario than in the business-as-usual baseline.

The results show that the accessibility impacts of TransBrasil become consistently smaller for longer time thresholds in both scenarios. This is because the BRT becomes accessible to increasingly distant areas as longer cutoff times are considered. The population living in distant areas, however, would need to spend a larger portion of their travel time budget to reach a BRT station, which leaves less time to travel inside the BRT corridor and benefit from its speed and connectivity. It is thus expected that people living in areas further away from the new project will have smaller benefits. Consequently, when the accessibility impact of a project is measured using longer time thresholds, the results include areas further afield, which lowers the overall average gain in accessibility. 
Table 1. Summary of the impact of the TransBrasil BRT project on people's access to job opportunities within various travel time thresholds under partial and full operation scenarios. Rio de Janeiro.

\begin{tabular}{|c|c|c|c|c|c|c|}
\hline \multirow{2}{*}{ Scenario } & & & \multicolumn{4}{|c|}{ Travel time threshold (minutes) } \\
\hline & & & 30 & 60 & 90 & 120 \\
\hline \multirow{3}{*}{ Full operation } & \multicolumn{2}{|c|}{ Average accessibility change $*$} & $13.3 \%$ & $11.3 \%$ & $4.2 \%$ & $2.4 \%$ \\
\hline & \multirow{2}{*}{$\begin{array}{l}\text { Population who gained } \\
\text { access to jobs }\end{array}$} & $\begin{array}{l}\text { Absolute } \\
\text { (in millions) }\end{array}$ & 0.8 & 3.6 & 4.8 & 4.3 \\
\hline & & $\begin{array}{l}\% \text { relative to } \\
\text { city population }\end{array}$ & $13.7 \%$ & $58.5 \%$ & $78.5 \%$ & $71.0 \%$ \\
\hline \multirow{3}{*}{ Partial operation } & \multicolumn{2}{|c|}{ Average accessibility change $*$} & $10.8 \%$ & $4.9 \%$ & $2.3 \%$ & $2.0 \%$ \\
\hline & \multirow{2}{*}{$\begin{array}{l}\text { Population who gained } \\
\text { access to jobs }\end{array}$} & $\begin{array}{l}\text { Absolute } \\
\text { (in millions) }\end{array}$ & 0.7 & 3.2 & 4.6 & 3.8 \\
\hline & & $\begin{array}{l}\% \text { relative to } \\
\text { city population }\end{array}$ & $12.0 \%$ & $52.0 \%$ & $76.1 \%$ & $62.2 \%$ \\
\hline
\end{tabular}

* Population-weighted mean increase in the number of jobs accessible via public transport and walking within specified travel time threshold.

A counterintuitive result in Table 1 is that the number of people who would have any accessibility gain due to the new BRT gradually increases when considering longer time thresholds up to 90 minutes but then declines for 120 minutes. This happens because cumulative opportunity measures only grasp accessibility changes when travel times between origindestination pairs are pushed across the time threshold in question. This happened to some locations that are colored in the 90-minute map but not in the 120-minute maps of Figure 3 (below). The population living in those areas was already relatively well served by the public transport network, so the proposed BRT would only marginally improve their accessibility under a 90-minute cutoff time but it would bring no accessibility again with a 120-minute threshold.

Accessibility gains brought about by TransBrasil will be higher in the surrounding areas of the new corridor but will not be limited to them due to network connectivity effects. Figure 3 illustrates the spatial distribution of accessibility gains promoted by TransBrasil in its partial and full scenarios. Under shorter travel times, accessibility gains are, as expected, larger along the new BRT. In some of these areas, the number of jobs accessible under 60 minutes would more than double compared to the business-as-usual baseline. Nonetheless, the accessibility impacts of TransBrasil are more than local. When longer time thresholds are considered, accessibility gains 
become smaller and more spatially distributed towards the west of Rio, which is generally less populated and economically developed. Figure 3 also shows how accessibility gains spread further along other major transport corridors, illustrating an important network effect of how future BRT will connect to Rio's public transport network.

For every cutoff time, the full construction of TransBrasil can bring higher accessibility impacts to a larger share of the population than the partial operation scenario. This will happen in part because the complete construction of TransBrasil will make it easier for people living in the north region to reach the city center, where most of the job opportunities are concentrated. This final stretch into the city center will significantly increase the connectivity of the proposed BRT to the rest of Rio's transport network via the light-rail, commuter rail and subway systems. This will also benefit people living in the southern part of the city, who will be able to connect to the new BRT in the city center and thus more easily access the job opportunities along the TransBrasil corridor towards the north. 
FIGURE 3. Variation in the proportion of formal jobs accessible within various travel time thresholds via public transport and walking under full (A) and partial (B) operation scenarios of the TransBrasil BRT project. Rio de Janeiro.

(A)

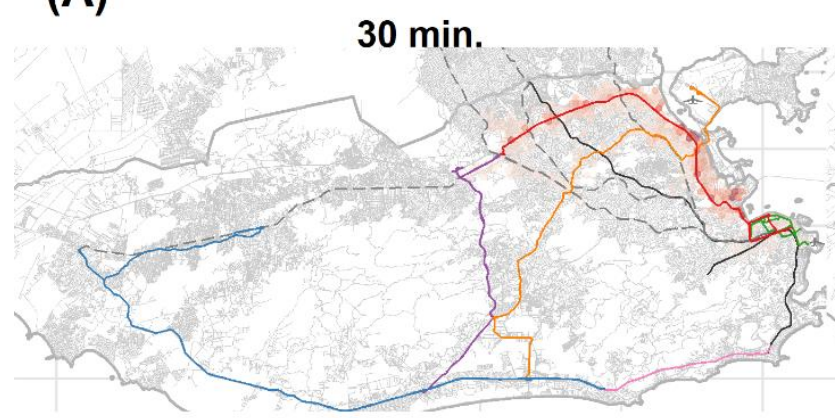

$60 \mathrm{~min}$.

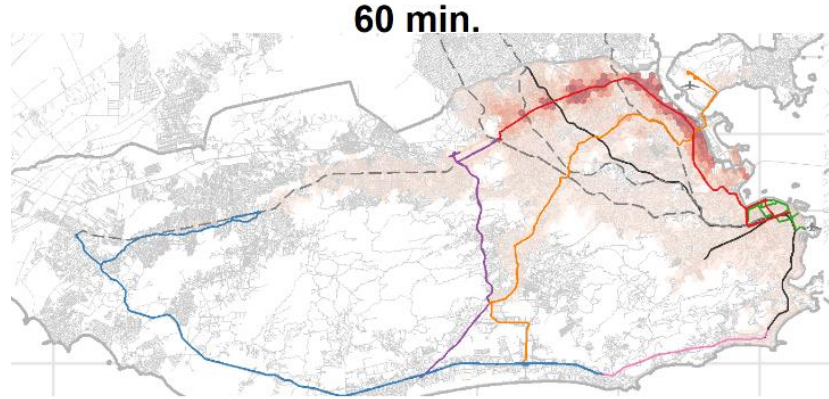

$90 \mathrm{~min}$.

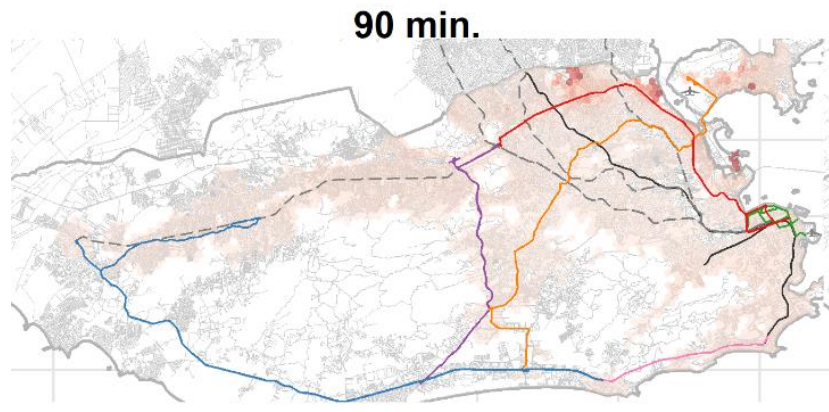

$120 \mathrm{~min}$.

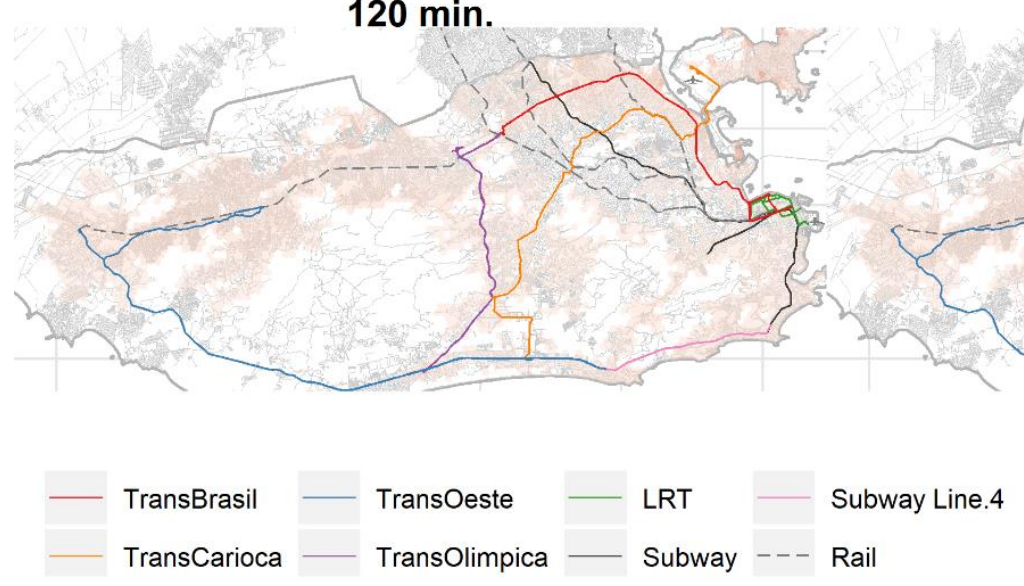

(B)

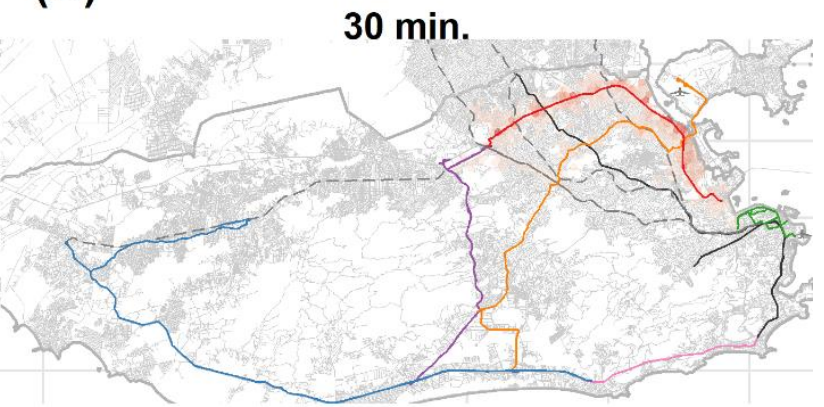

$60 \mathrm{~min}$.

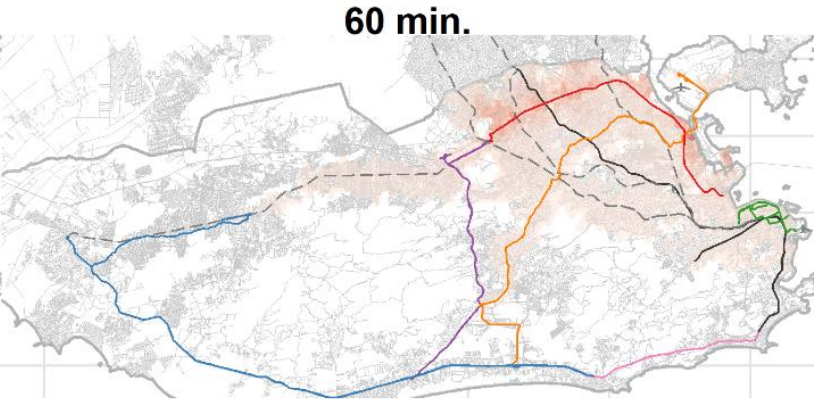

$90 \mathrm{~min}$.

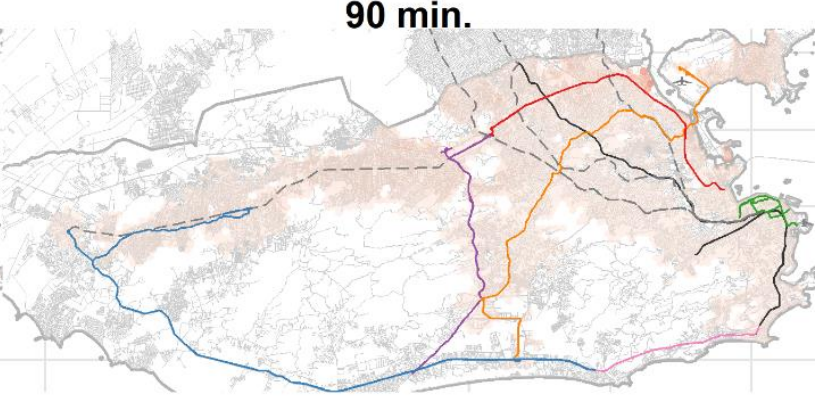

$120 \mathrm{~min}$.

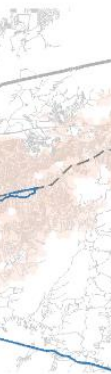

$120 \mathrm{~min}$. 
Due to limitations of data availability, it was not possible to measure the accessibility impacts of TransBrasil outside the boundaries of the city of Rio (shown in dark gray in Figures 3 and 4). Nonetheless, the figures suggest that accessibility gains from this BRT will likely extend to neighboring municipalities, which have relatively poorer populations and lower availability of transport services. This suggests that the TransBrasil BRT would have had even more progressive effects had these municipalities been incorporated into the analysis.

A central question to consider from a transportation equity point of view is to what extent the implementation of the proposed transport investment will contribute to reducing inequality of access to opportunities, particularly by improving the access of lower-income groups. The results show that both partial and full scenarios will have progressive effects - i.e. they will bring larger accessibility benefits to lower- than to higher-income areas, particularly under shorter travel time thresholds. Figure 4 uses box plots to show how of job accessibility gains vary income deciles at travel time limits of 30, 60, 90 and 120 minutes. It indicates that TransBrasil will bring higher accessibility gains to lower income classes, but also that the magnitude of these gains differs considerably depending on the travel time limit. With a 60-minute threshold, for example, the complete implementation of the BRT will increase job accessibility in the city by $11.3 \%$ on average, while areas in the two poorest income deciles will experience a $23 \%$ average rise in their accessibility to employment opportunities. To a large extent, this is because of the layout of this corridor, which cuts across various low-income neighborhoods with high population density and improves their connection to areas of high job concentration, particularly in the city center. Figure 4 also shows how the magnitude of the accessibility impacts promoted by TransBrasil gradually declines for longer travel time thresholds, and this decline is particularly noticeable for lower income deciles. The TransBrasil corridor will have more progressive effects when considering a threshold of 30 minutes. It gradually becomes more neutral when longer travel times are considered but it is still slightly progressive at a threshold of 120 minutes. In other words, the progressive redistribution of accessibility brought about by the TransBrasil project cannot be considered in isolation from the cutoff time value that is used in the cumulative opportunity analysis. 
FIGURE 4. Distribution of gains in job accessibility via public transport and walking by income groups under partial and full operation scenarios given various travel time thresholds. Rio de Janeiro

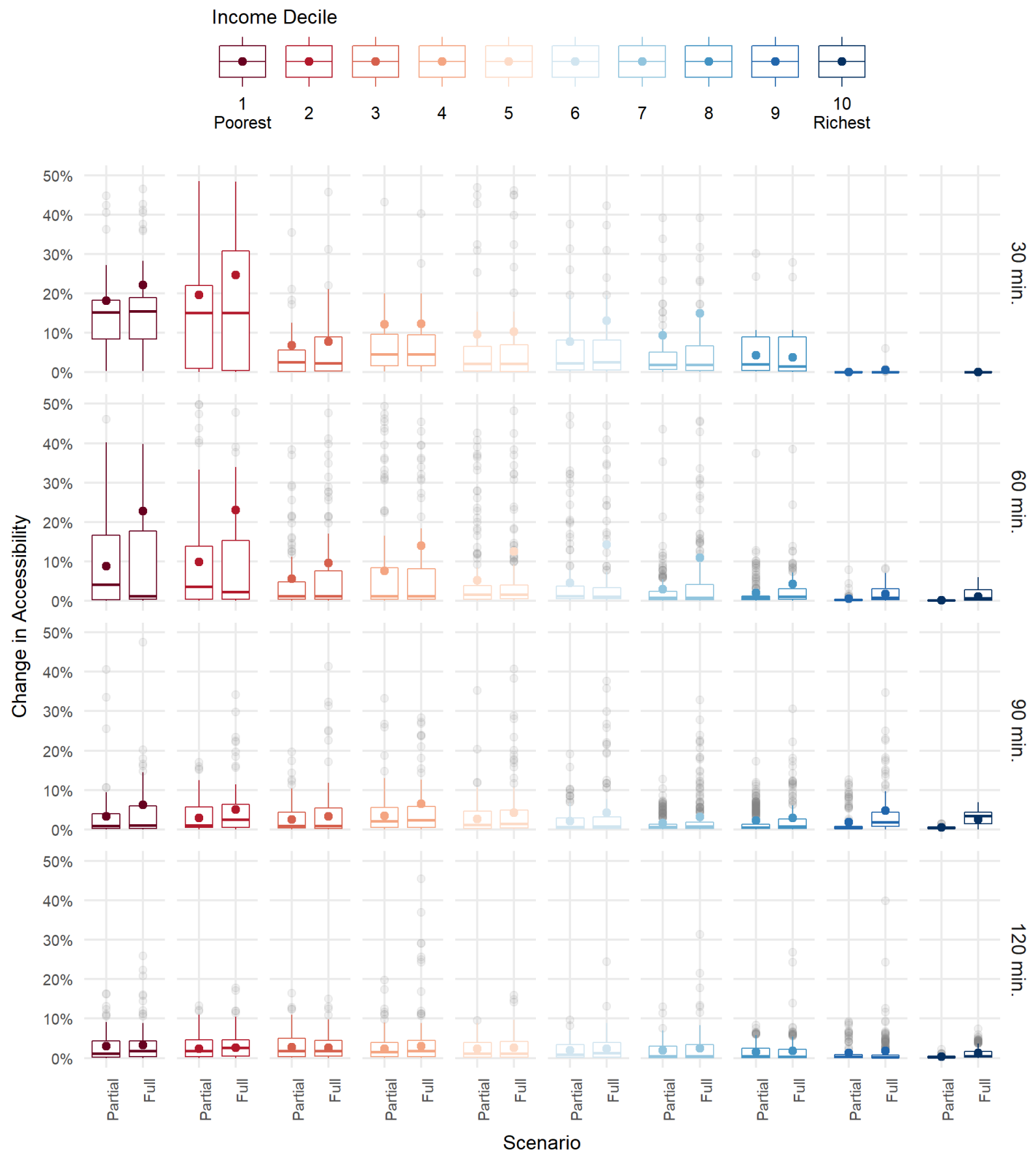

Note: Chart only considers the grid cells where there will be a change in accessibility levels caused by the partial and full implementation of the BRT project. 
The boxplots also illustrate how, compared to the partial implementation of the TransBrasil corridor, the full implementation would bring relatively higher accessibility gains to larger numbers of people. This can be seen in the rise of average accessibility - indicated by the colored dots - which would be particularly more pronounced for lower-income classes once the project is fully implemented. The horizontal bar inside the boxplots of Figure 4 represents the median accessibility gains within each income decile. Median accessibility levels would generally decrease from partial to full operation scenario. This is because under the full operation scenario, the accessibility impacts of the new BRT would extend to a larger number of people in areas further afield, as seen in Figures 3. However, because these areas have relatively smaller accessibility gains, the expansion of the BRT's area of influence increases the number of beneficiaries at the same time as it drives the median gains in accessibility down. These conclusions are corroborated by a spatial regression model (presented in a Statistical Annex). The regression analysis confirms that the difference in accessibility gains between people from different income levels is large enough to be considered statistically significant. Moreover, the analysis provides robust evidence that the results are sensitive to MTUP, i.e. that that choosing different time thresholds can lead to conclusions which are equally statistically significant despite being substantially different.

Overall, these results suggest that the implementation of the TransBrasil BRT can significantly improve the access to job opportunities for a large share of Rio's population, and particularly for lower-income areas. However, these results vary substantially depending on what time threshold is chosen for the analysis. While the implementation of this new BRT would have more progressive and higher accessibility impacts under shorter travel times (30 and 60 minutes), it will have more neutral effects with smaller impact with longer time thresholds (90 and 120 minutes). Moreover, the full implementation of the TransBrasil corridor will promote greater accessibility gains compared to its partial construction, and extending this BRT into the city center will make this project slightly more progressive from a distributional point of view. Finally, the TransBrasil corridor stands out as a far more equitable investment that promotes larger accessibility gains for lower-income areas when compared to the accessibility impacts of the other recent transport investments in Rio de Janeiro (Pereira, 2018; Pereira, Banister, et al., 2017). 


\section{Conclusion}

This study evaluated of how different scenarios of a major BRT project currently under development in Rio de Janeiro may impact employment accessibility of different income groups and how these results vary when using different travel time thresholds. The findings indicate that the full implementation of the TransBrasil corridor will promote greater accessibility gains and make this project slightly more progressive from a distributional point of view than its partial construction. From a Rawlsian perspective, both scenarios would move Rio towards a more equitable transportation system because they increase accessibility across areas of all income levels, but they prioritize improving accessibility for areas with low average income. While it would be unrealistic to expect every neighborhood in a city to have the same level of access to job opportunities, the results of this paper suggest that the construction of this BRT would at least reduce inequalities in access to opportunities by increasing accessibility levels of poorer communities that are more transit-dependent. From this angle, any of the scenarios of the TransBrasil corridor will stand out as a far more equitable investment than the other recent transport investments in Rio(Pereira, 2018; Pereira, Banister, et al., 2017).

The results also reveal that the size of the accessibility impacts of the TransBrasil project as well as its distribution by income level vary substantially depending on the time threshold chosen for the cumulative opportunity accessibility analysis. While the implementation of this BRT will have more progressive and higher accessibility impacts under shorter travel times (30 and 60 minutes), it will have more neutral effects and smaller impact with longer time thresholds (90 and 120 minutes). This result draws attention to a broader question about the extent to which the equity appraisal of transportation projects is sensitive to the modifiable temporal unit problem (MTUP). Looking specifically at the boundary effect of MTUP, this study shows that conclusions of equity assessments of transportation projects are dependent on time threshold choice. It points to how some methodological choices such as this one can have important but little discussed implications for policy evaluation. More importantly, it suggests that the most common practice adopted by academic studies and transport agencies when evaluating the accessibility impacts of transportation projects can lead to misleading or partial conclusions if these methodological choices are made uncritically. 
It is important to ask whether analyses using various time thresholds lead to differences in results that would be sufficiently large to suggest substantial modifications in the transport policy proposed. In the case of the TransBrasil BRT, the size of average accessibility gains could vary five-fold and the impact of the project changes from progressive to neutral depending on the cutoff time considered. This can have important implications for decision making if these results are incorporated in some sort of cost benefit analysis or multi-criteria analysis. This, however, is a study of a particular project and city. It is reasonable to expect that the sensitivity of results to cutoff time varies according to the characteristics of the transport intervention and the city under analysis. The findings of this paper suggest that future research on the equity appraisal of transportation projects should pay attention to the modifiable temporal unit problem and include sensitivity analysis and look more carefully at distributional effects.

There is currently no standard approach to overcome the boundary effect in MTUP. One way to minimize MTUP when working with cumulative opportunity measures could be to estimate accessibility levels under various time thresholds and then calculate the weighted average accessibility across all thresholds. Although this approach would avoid the arbitrariness of choosing a single time threshold, it still requires some ad-hoc decision on which and how many cut-off points should be considered. Another alternative would be to use other accessibility measures that require selecting a single time threshold - e.g., log-sum or gravitational metrics. Nonetheless, these measures also rely on parameters that are defined ad-hoc, such as distance/time decay factors which greatly influence accessibility estimates (Stępniak \& Rosik, 2017). According to Kwan \& Weber (2008), space-time accessibility measures are not sensitive to the spatial MAUP, but further investigation will be necessary to examine whether this type of metric can also overcome MTUP. In any case, these alternative accessibility measures have other limitations, such as being data-hungry and less transparent/easy to communicate to policymakers. Just as there is no single best method to measure accessibility (Neutens et al., 2010; van Wee \& Geurs, 2011), there is no single universal threshold that is appropriate for every transportation project, trip purpose, social group and urban context. This case study of the city of Rio illustrates why simple sensitivity analysis should be incorporated more often in future research.

A limitation of this study is that it was circumscribed to the city of Rio de Janeiro due to lack of data for neighboring municipalities. Nonetheless, the accessibility benefits of the 
TransBrasil project are likely to spill over to nearby municipalities and thus benefit relatively poorer populations and people with lower availability of transport services. This issue raises questions related to the planning and financing of transport projects that are under the responsibility of a single municipality but which have wider accessibility impacts that cross borders in urban agglomerations lacking metropolitan governance. Another limitation of this paper is that it focuses on the short-term impacts of the BRT project. It thus overlooks the longterm feedback between transport investments and reorganization of land use patterns. Further research is necessary to understand the long-term equity effects of transport investments on real estate values (Jun, 2012; Stokenberga, 2014) and gentrification processes (Gaffney, 2016). Other research questions that deserve careful attention from future studies include the long-term health effects transport projects and issues of governance and participatory decision-making which are also of key importance for the co-production of fair transport policies (Boisjoly \& Yengoh, 2017; Fainstein, 2010).

Finally, this study has only considered the boundary effect of MTUP. The segmentation effect has received more attention in previous studies which have shown that the variation of public transport service levels across the day and in different days of the week can have important equity implications (Fan et al., 2012; Farber et al., 2014). Both the boundary and the aggregation effects, on the other hand, have been largely overlooked in the literature thus far. This paper has shown how the boundary effect of choosing a travel time threshold has important implications for transportation equity analysis. Much more research is needed to understand how and to what extent other methodological decisions related to MTUP could influence the conclusions of transport project appraisals. 


\section{Acknowledgments}

The author would like to thank the editor and reviewers for useful and constructive comments.

The author would like to thank David Banister and Tim Schwanen for their thoughtful comments on previous versions of this paper. This work was supported by Capes Foundation, Ministry of Education, Brazil [Grant Number BEX 1397/13-3], the Brazilian Institute for Applied Economic Research (Ipea) and the Lee Schipper Memorial Scholarship.

\section{References}

Akyelken, N. (2017). Mobility-Related Economic Exclusion: Accessibility and Commuting Patterns in Industrial Zones in Turkey. Social Inclusion, 5(4), 175-182.

Anderson, P., Levinson, D., \& Parthasarathi, P. (2013). Accessibility Futures. Transactions in GIS, 17(5), 683-705. doi:10.1111/tgis.12024

Apparicio, P., Abdelmajid, M., Riva, M., \& Shearmur, R. (2008). Comparing alternative approaches to measuring the geographical accessibility of urban health services: Distance types and aggregation-error issues. International Journal of Health Geographics, 7(1), 7. doi: $10.1186 / 1476-072 X-7-7$

Banister, D., \& Hickman, R. (2006). How to design a more sustainable and fairer built environment: transport and communications. Intelligent Transport Systems, IEE Proceedings, 153(4), 276-291. doi:10.1049/ip-its:20060009

Birch, C. P. D., Oom, S. P., \& Beecham, J. A. (2007). Rectangular and hexagonal grids used for observation, experiment and simulation in ecology. Ecological Modelling, 206(3), 347359. doi:10.1016/j.ecolmodel.2007.03.041

Blanco, J., Lucas, K., Schafran, A., ... Apaolaza, R. (2018). Contested mobilities in the Latin American context. Journal of Transport Geography. doi:10.1016/j.jtrangeo.2018.01.006

Boisjoly, G., \& El-Geneidy, A. (2016). Daily fluctuations in transit and job availability: A comparative assessment of time-sensitive accessibility measures. Journal of Transport Geography, 52, 73-81. doi:10.1016/j.jtrangeo.2016.03.004

Boisjoly, G., \& El-Geneidy, A. M. (2017). How to get there? A critical assessment of accessibility objectives and indicators in metropolitan transportation plans. Transport Policy, 55, 38-50. doi:10.1016/j.tranpol.2016.12.011

Boisjoly, G., \& Yengoh, G. T. (2017). Opening the door to social equity: local and participatory approaches to transportation planning in Montreal. European Transport Research Review, 9(3), 43. doi:10.1007/s12544-017-0258-4 
Brazil. (2009). Caderno de Legados Urbano e Ambiental. Rio 2016 Cidade Candidata. Sport Ministry.

Retrieved

from http://www.esporte.gov.br/arquivos/rio2016/cadernoLegadosUrbanoAmbiental.pdf

Câmara, P., \& Banister, D. (1993). Spatial inequalities in the provision of public transport in Latin American cities. Transport Reviews, 13(4), 351-373. doi:10.1080/01441649308716857

Candida, S. (2017, April 11). Perguntas e respostas sobre a retomada das obras do BRT Transbrasil. $O$ Globo. Retrieved from https://oglobo.globo.com/rio/perguntas-respostassobre-retomada-das-obras-do-brt-transbrasil-21189095

Casas, I. (2007). Social exclusion and the disabled: An accessibility approach. Professional Geographer, 59(4), 463-477. doi:10.1111/j.1467-9272.2007.00635.x

Cheng, T., \& Adepeju, M. (2014). Modifiable Temporal Unit Problem (MTUP) and Its Effect on Space-Time Cluster Detection. PLOS ONE, 9(6), e100465. doi:10.1371/journal.pone.0100465

Ciommo, F. D., \& Shiftan, Y. (2017). Transport equity analysis. Transport Reviews, 37(2), 139151. doi:10.1080/01441647.2017.1278647

Conway, M. W., Byrd, A., \& Eggermond, M. van. (2018). Accounting for uncertainty and variation in accessibility metrics for public transport sketch planning. Journal of Transport and Land Use, 11(1). Retrieved from https://www.jtlu.org/index.php/jtlu/article/view/1074

Delmelle, E. C., \& Casas, I. (2012). Evaluating the spatial equity of bus rapid transit-based accessibility patterns in a developing country: The case of Cali, Colombia. Transport Policy, 20, 36-46. doi:10.1016/j.tranpol.2011.12.001

El-Geneidy, A., Cerdá, A., Fischler, R., \& Luka, N. (2011). Evaluating the Impacts of Transportation Plans Using Accessibility Measures. Canadian Journal of Urban Research, 20(1), 81-104.

El-Geneidy, A., Levinson, D., Diab, E., ... Loong, C. (2016). The cost of equity: Assessing transit accessibility and social disparity using total travel cost. Transportation Research Part A: Policy and Practice, 91, 302-316. doi:10.1016/j.tra.2016.07.003

Fainstein, S. S. (2010). The just city. Ithaca: Cornell University Press.

Fan, Y., Guthrie, A. E., \& Levinson, D. M. (2012). Impact of light rail implementation on labor market accessibility: A transportation equity perspective. Journal of Transport and Land Use, 5(3). Retrieved from https://www.jtlu.org/index.php/jtlu/article/view/240

Farber, S., \& Grandez, M. (2017). Transit accessibility, land development and socioeconomic priority: A typology of planned station catchment areas in the Greater Toronto and Hamilton Area. Journal of Transport and Land Use, 10(1). doi:10.5198/jtlu.2017.980

Farber, S., Morang, M. Z., \& Widener, M. J. (2014). Temporal variability in transit-based accessibility to supermarkets. Applied Geography, 53, 149-159. doi:10.1016/j.apgeog.2014.06.012 
França, R. (2016, December 11). Ônibus perdem passageiros durante a crise. O Globo. Retrieved from https://oglobo.globo.com/rio/onibus-perdem-passageiros-durante-crise-20625497

Gaffney, C. (2010). Mega-events and socio-spatial dynamics in Rio de Janeiro, 1919-2016. Journal of Latin American Geography, 9(1), 7-29. doi:10.1353/lag.0.0068

Gaffney, C. (2016). Gentrifications in pre-Olympic Rio de Janeiro. Urban Geography, 37(8), 1132-1153. doi:10.1080/02723638.2015.1096115

Geurs, K., \& va Eck, J. R. R. (2003). Evaluation of Accessibility Impacts of Land-Use Scenarios: The Implications of Job Competition, Land-Use, and Infrastructure Developments for the Netherlands. Environment and Planning B: Planning and Design, 30(1), 69-87. doi:10.1068/b12940

Geurs, K., \& van Wee, B. (2004). Accessibility evaluation of land-use and transport strategies: review and research directions. Journal of Transport Geography, 12(2), 127-140. doi:10.1016/j.jtrangeo.2003.10.005

Givoni, M. (2016). Winning the Last Mile. Built Environment, 42(4), 517-522.

Golub, A., \& Martens, K. (2014). Using principles of justice to assess the modal equity of regional transportation plans. Journal of Transport Geography, 41, 10-20. doi:10.1016/j.jtrangeo.2014.07.014

Guthrie, A., Fan, Y., \& Das, K. V. (2017). Accessibility Scenario Analysis of a Hypothetical Future Transit Network: Social Equity Implications of a General Transit Feed Specification-Based Sketch Planning Tool. Transportation Research Record: Journal of the Transportation Research Board, 2671, 1-9. doi:10.3141/2671-01

Huang, Q., \& Wong, D. W. S. (2015). Modeling and Visualizing Regular Human Mobility Patterns with Uncertainty: An Example Using Twitter Data. Annals of the Association of American Geographers, 105(6), 1179-1197. doi:10.1080/00045608.2015.1081120

IBGE. (2016). Grade Estatística 2010. Retrieved from http://mapas.ibge.gov.br/interativos/grade.html

Ipea, UNPD, \& FJP. (2015). Atlas do desenvolvimento humano nas regiões metropolitanas brasileiras. Retrieved November 20, 2015, from http://www.atlasbrasil.org.br/

Jun, M.-J. (2012). Redistributive effects of bus rapid transit (BRT) on development patterns and property values in Seoul, Korea. Transport Policy, 19(1), 85-92. doi:10.1016/j.tranpol.2011.09.003

Karner, A., \& Niemeier, D. (2013). Civil rights guidance and equity analysis methods for regional transportation plans: a critical review of literature and practice. Journal of Transport Geography, 33, 126-134. doi:10.1016/j.jtrangeo.2013.09.017

Kassens-Noor, E., Gaffney, C., Messina, J., \& Phillips, E. (2016). Olympic Transport Legacies: Rio de Janeiro's Bus Rapid Transit System. Journal of Planning Education and Research, 0739456X16683228. doi:10.1177/0739456X16683228

Kwan, M.-P. (2018). The Limits of the Neighborhood Effect: Contextual Uncertainties in Geographic, Environmental Health, and Social Science Research. Annals of the American Association of Geographers, O(0), 1-9. doi:10.1080/24694452.2018.1453777 
Kwan, M.-P., \& Weber, J. (2008). Scale and accessibility: Implications for the analysis of land use-travel interaction. Applied Geography, 28(2), 110-123. doi:10.1016/j.apgeog.2007.07.002

Lago, L. C. do. (2000). Desigualdades e segregação na metrópole: o Rio de Janeiro em tempo de crise. Observatório IPPUR/UFRJ-FASE. Retrieved from http://web.observatoriodasmetropoles.net/new/images/abook_file/desigualdade_metropol erj_lucianalago.pdf

Lisboa, V. (2017). Prefeitura do Rio retoma obras do BRT Transbrasil. Agência Brasil - Últimas Notícias Do Brasil e Do Mundo. Rio de Janeiro. Retrieved from http://agenciabrasil.ebc.com.br/geral/noticia/2017-04/rio-retoma-obras-do-corredorexpresso-de-onibus-articulados

Logit. (2014). Relatorio Final: Revisão do Estudo TransBrasil - Área Central. São Paulo: Logit. Retrieved from http://www.rio.rj.gov.br/web/pmus/documentos

Lucas, K. (2012). Transport and social exclusion: Where are we now? Transport Policy, 20, 105-113. doi:10.1016/j.tranpol.2012.01.013

Lucas, K., van Wee, B., \& Maat, K. (2015). A method to evaluate equitable accessibility: combining ethical theories and accessibility-based approaches. Transportation, 1-18. doi:10.1007/s11116-015-9585-2

Magalhães, L. E., \& Rodrigues, R. (2017, June 6). Sistema BRT completa 5 anos sem motivos para comemorar. $O$ Globo. Retrieved from https://oglobo.globo.com/rio/sistema-brtcompleta-5-anos-sem-motivos-para-comemorar-21439782

Manaugh, K., Badami, M. G., \& El-Geneidy, A. M. (2015). Integrating social equity into urban transportation planning: A critical evaluation of equity objectives and measures in transportation plans in North America. Transport Policy, 37, 167-176. doi:10.1016/j.tranpol.2014.09.013

Manaugh, K., \& El-Geneidy, A. (2012). Who Benefits from New Transportation Infrastructure? Using Accessibility Measures to Evaluate Social Equity in Public Transport Provision. In K. Martens, K. Geurs, K. Krizek, \& A. Reggiani (Eds.), Accessibility Analysis and Transport Planning: Challenges for Europe and North America. Cheltenham, UK; Northampton, MA: Edward Elgar. Retrieved from http://www.kevinmanaugh.com/resources/Transit_plan_equity.pdf

Martens, K. (2012). Justice in transport as justice in accessibility: applying Walzer's 'Spheres of Justice' to the transport sector. Transportation, 39(6), 1035-1053. doi:10.1007/s11116012-9388-7

Martens, K., \& Golub, A. (2012). A justice-theoretic exploration of accessibility measures. In K. Geurs, K. J. Krizek, A. Reggiani, \& Network on European Communications and Transport Activity Research (Eds.), Accessibility analysis and transport planning: challenges for Europe and North America (pp. 195-210). Cheltenham: Edward Elgar. 
Motte-Baumvol, B., Aguilera, A., Bonin, O., \& Nassi, C. D. (2016). Commuting patterns in the metropolitan region of Rio de Janeiro. What differences between formal and informal jobs? Journal of Transport Geography, 51, 59-69. doi:10.1016/j.jtrangeo.2015.10.019

Neutens, T., Delafontaine, M., Scott, D. M., \& De Maeyer, P. (2012). An analysis of day-to-day variations in individual space-time accessibility. Journal of Transport Geography, 23, 81-91. doi:10.1016/j.jtrangeo.2012.04.001

Neutens, T., Schwanen, T., Witlox, F., \& Maeyer, P. D. (2010). Equity of urban service delivery: a comparison of different accessibility measures. Environment and Planning A, 42(7), 1613 - 1635. doi:10.1068/a4230

Niehaus, M., Galilea, P., \& Hurtubia, R. (2016). Accessibility and equity: An approach for wider transport project assessment in Chile. Research in Transportation Economics, 59, 412422. doi:10.1016/j.retrec.2016.05.003

Omer, I. (2006). Evaluating accessibility using house-level data: A spatial equity perspective. Computers, Environment and Urban Systems, 30(3), 254-274. doi:10.1016/j.compenvurbsys.2005.06.004

Ortega, E., López, E., \& Monzón, A. (2012). Territorial cohesion impacts of high-speed rail at different planning levels. Journal of Transport Geography, 24, 130-141. doi:10.1016/j.jtrangeo.2011.10.008

Owen, A., \& Levinson, D. M. (2015). Modeling the commute mode share of transit using continuous accessibility to jobs. Transportation Research Part A: Policy and Practice, 74, 110-122. doi:10.1016/j.tra.2015.02.002

Palmateer, C., Owen, A., \& Levinson, D. M. (2016). Accessibility Evaluation of the Metro Transit A-Line (Report). Accessibility Observatory, University of Minnesota. Retrieved from http://conservancy.umn.edu/handle/11299/180900

Papa, E., Silva, C., Brömmelstroet, M. te, \& Hull, A. (2015). Accessibility instruments for planning practice: a review of European experiences. Journal of Transport and Land Use, $O(0)$. Retrieved from https://www.jtlu.org/index.php/jtlu/article/view/585

Pereira, R. H. M. (2018). Transport legacy of mega-events and the redistribution of accessibility to urban destinations. Cities, 81, 45-60. doi:10.1016/j.cities.2018.03.013

Pereira, R. H. M., Banister, D., Schwanen, T., \& Wessel, N. (2017). Distributional effects of transport policies on inequalities in access to opportunities in Rio de Janeiro. SocArXiv. doi:10.31235/osf.io/cghx2

Pereira, R. H. M., \& Schwanen, T. (2013). Commute Time in Brazil (1992-2009): differences between metropolitan areas, by income levels and gender (Texto para Discussão No. 1813a). Brasília: Institute for Applied Economic Research - Ipea. Retrieved from http://repositorio.ipea.gov.br/handle/11058/964

Pereira, R. H. M., Schwanen, T., \& Banister, D. (2017). Distributive justice and equity in transportation. Transport Reviews, 37(2), 170-191. doi:10.1080/01441647.2016.1257660

Rawls, J. (1999). A theory of justice (revised edition.). Cambridge, Mass.: Belknap Press of Harvard University Press. 
Rawls, J. (2001). Justice as fairness: a restatement. Cambridge, Mass; London: Harvard University Press.

Ribeiro, L. C. de Q. (Ed.). (2014). The Metropolis of Rio de Janeiro: a space in transition (1st ed.). Rio de Janeiro: Letra Capital.

Ribeiro, L. C. de Q., Rodrigues, J. M., \& Corrêa, F. S. (2010). Segregação residencial e emprego nos grandes espaços urbanos brasileiros. Cadernos Metrópole. ISSN (impresso) 15172422; (eletrônico) 2236-9996, 12(23). Retrieved from http://revistas.pucsp.br/index.php/metropole/article/view/5921

RJTV. (2018, January 23). "Mãos à Obra" prende cinco pessoas investigadas por receber propina da Transbrasil. Rio de Janeiro, Brasil. Retrieved from https://globoplay.globo.com/v/6441668/

Rodrigues, R. (2017, June 28). Metrô faz oferta promocional após queda de 14,5\% nas viagens Jornal $\mathrm{O}$ Globo. Retrieved from https://oglobo.globo.com/rio/metro-faz-ofertapromocional-apos-queda-de-145-nas-viagens-21527565

Ryan, J., Wretstrand, A., \& Schmidt, S. M. (2015). Exploring public transport as an element of older persons' mobility: A Capability Approach perspective. Journal of Transport Geography, 48, 105-114. doi:10.1016/j.jtrangeo.2015.08.016

Scholl, L., Bouillon, C. P., Oviedo, D., ... Jansson, M. (2016). Urban Transport and Poverty: Mobility and Accessibility Effects of IDB-supported BRT Systems in Cali and Lima. Washington, DC: Inter-American Development Bank.

Smeds, E., McArthur, J., \& Robin, E. (2017). Equitable transport provision for night-time workers in 24-hour London. London: UCL City Leadership Laboratory. Retrieved from https://docs.wixstatic.com/ugd/6c6416_060ed39e7f74435eae2b409c756d101d.pdf

Souza, P. H. G. F. de. (2015). Income distribution according to Brazilian household surveys: harmonization and comparison of Census, PNAD and POF data. Revista Brasileira de Estudos de População, 32(1), 165-188. doi:10.1590/S0102-30982015000000009

Stępniak, M., \& Jacobs-Crisioni, C. (2017). Reducing the uncertainty induced by spatial aggregation in accessibility and spatial interaction applications. Journal of Transport Geography, 61, 17-29. doi:10.1016/j.jtrangeo.2017.04.001

Stępniak, M., \& Rosik, P. (2017). The Role of Transport and Population Components in Change in Accessibility: the Influence of the Distance Decay Parameter. Networks and Spatial Economics. doi:10.1007/s11067-017-9376-8

Stokenberga, A. (2014). Does Bus Rapid Transit Influence Urban Land Development and Property Values: A Review of the Literature. Transport Reviews, 34(3), 276-296. doi:10.1080/01441647.2014.902404

Tan, P. Y., \& Samsudin, R. (2017). Effects of spatial scale on assessment of spatial equity of urban park provision. Landscape and Urban Planning, 158, 139-154. doi:10.1016/j.landurbplan.2016.11.001 
Tilahun, N., \& Fan, Y. (2014). Transit and job accessibility: an empirical study of access to competitive clusters and regional growth strategies for enhancing transit accessibility. Transport Policy, 33, 17-25. doi:10.1016/j.tranpol.2014.02.002

UN-HABITAT. (2010). State of the World's Cities 2010/2011-Cities for All: Bridging the Urban Divide (p. 244). UN-HABITAT. Retrieved from http://unhabitat.org/books/stateof-the-worlds-cities-20102011-cities-for-all-bridging-the-urban-divide/

van Wee, B., \& Geurs, K. (2011). Discussing equity and social exclusion in accessibility evaluations. European Journal of Transport and Infrastructure Research, 11(4). Retrieved from http://www.ejtir.tbm.tudelft.nl/issues/2011_04/abstracts/2011_04_01.asp

van Wee, B., \& Roeser, S. (2013). Ethical Theories and the Cost-Benefit Analysis-Based Ex Ante Evaluation of Transport Policies and Plans. Transport Reviews, 33(6), 743-760. doi:10.1080/01441647.2013.854281

Vasconcellos, E. A. de. (2001). Urban transport, environment, and equity: the case for developing countries. London, UK ;Sterling, VA: Earthscan.

Vasconcellos, E. A. de. (2014). Políticas de transporte no Brasil: a construção da mobilidade excludente. MANOLE.

Venter, C., Jennings, G., Hidalgo, D., \& Pineda, A. F. V. (2017). The equity impacts of bus rapid transit: A review of the evidence and implications for sustainable transport. International Journal of Sustainable Transportation, O(0), 1-13. doi:10.1080/15568318.2017.1340528

Zarur, C. (2017). Empresa de ônibus do Rio fecha por causa da crise. Retrieved October 5, 2017, from https://extra.globo.com/noticias/rio/empresa-de-onibus-do-rio-fecha-por-causa-dacrise-21258317.html

Zhang, M., \& Kukadia, N. (2005). Metrics of Urban Form and the Modifiable Areal Unit Problem. Transportation Research Record: Journal of the Transportation Research Board, 1902, 71-79. doi:10.3141/1902-09

Zuazo, P., Goulart, G., \& Rodrigues, R. (2017, December 29). Sistema de transporte no Rio anda para trás. Extra Online. Rio de Janeiro, Brasil. Retrieved from https://extra.globo.com/noticias/rio/sistema-de-transporte-no-rio-anda-para-tras22237449.html 
Appendix I - Stop sequence of the services planned to run in the TransBrasil BRT corridor
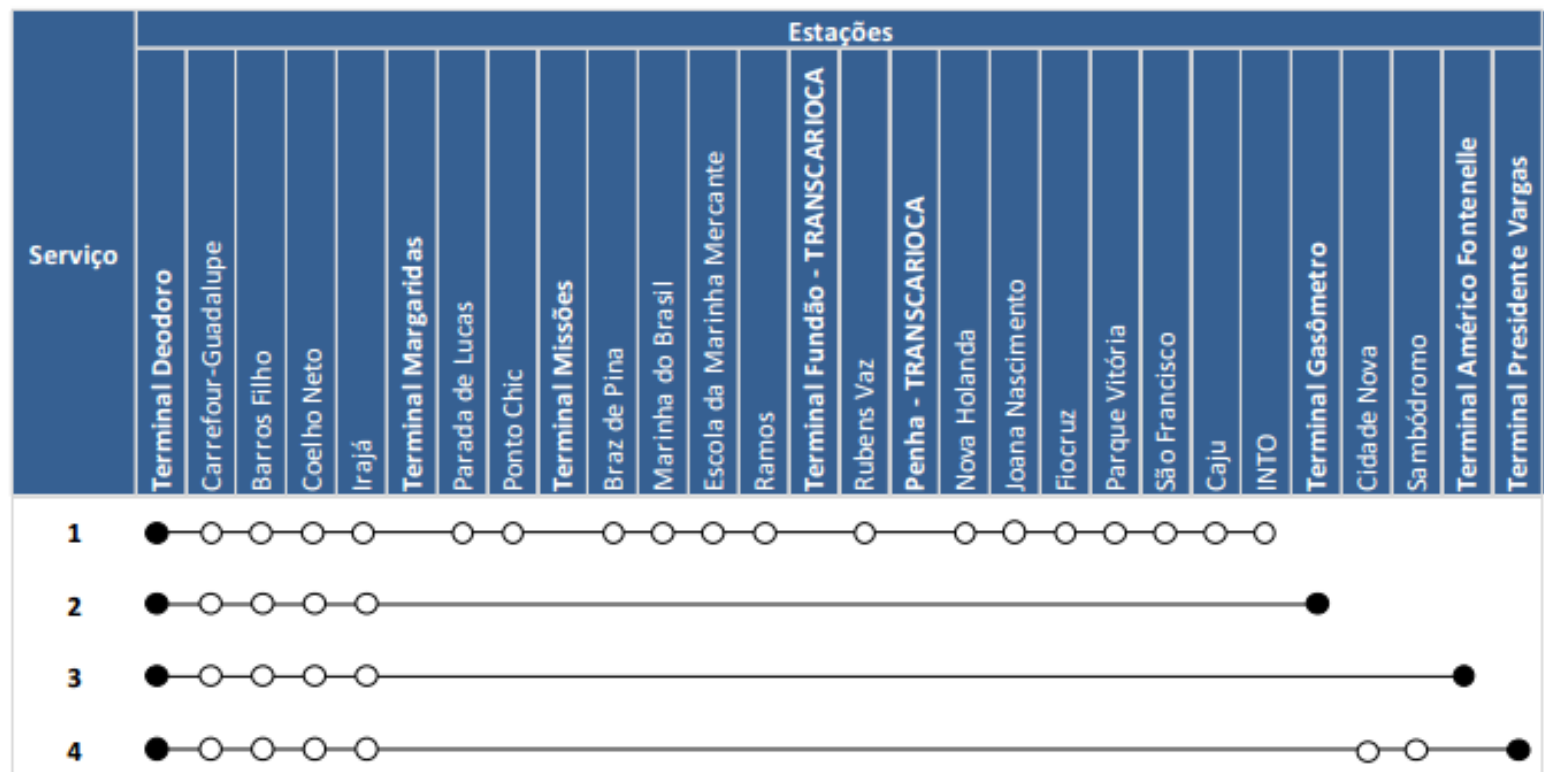

$$
5
$$$$
\text { - }-\mathrm{O}-\mathrm{O}-\mathrm{O}-\mathrm{O}-\mathrm{O}-\mathrm{O}-\mathrm{O}-\mathrm{O}-\mathrm{O}-\mathrm{O}-\mathrm{O}-\mathrm{O}-\mathrm{O}-\mathrm{O}
$$

6

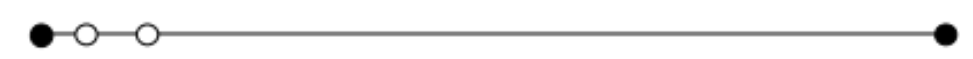

7

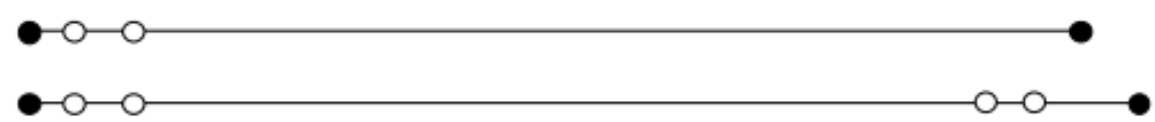

8

9

$-\mathrm{O}-\mathrm{O}-\mathrm{O}-\mathrm{O}-\mathrm{O}-\mathrm{O}-\mathrm{O}-\mathrm{O}-\mathrm{O}-\mathrm{O}-\mathrm{O}-\mathrm{O}$

10

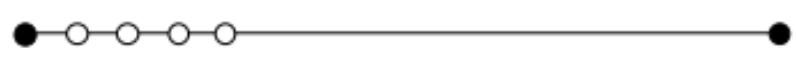

11

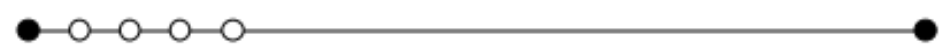

12

13

14

15

16

17

18

19

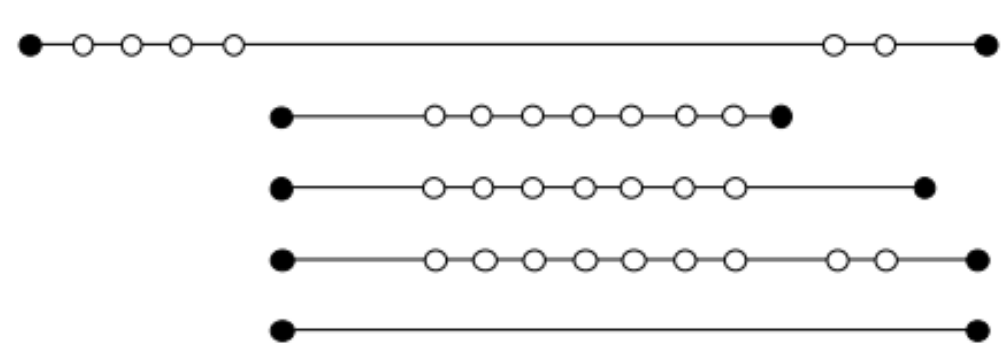

Source: Logit (2014, p.42) 
Pre-print published in the Journal of Transport Geography https://www.sciencedirect.com/science/article/pii/S0966692318302047

Appendix II - Operational information of the services planned to run in the TransBrasil BRT corridor

\begin{tabular}{|c|c|c|c|c|c|c|}
\hline \# & Route service name & $\begin{array}{l}\text { Total length } \\
\quad(\mathrm{Km}) *\end{array}$ & $\begin{array}{l}\text { Travel time } \\
\text { (minutes)* }\end{array}$ & $\begin{array}{c}\text { Average } \\
\text { speed } \\
(\mathrm{Km} / \mathbf{h}) *\end{array}$ & $\begin{array}{c}\begin{array}{c}\text { Frequency } \\
\text { (morning } \\
\text { peak) }\end{array} \\
\end{array}$ & $\begin{array}{l}\text { Headway } \\
\text { (min' sec") }\end{array}$ \\
\hline 1 & Terminal Deorodo - I.N.T.O. (Parador) & 50.0 & 98 & 30.6 & 72 & $0^{\prime} 45^{\prime \prime}$ \\
\hline 2 & Terminal Deorodo - Terminal Gasômetro (Semi-Direto/ Direto) & 51.5 & 94 & 32.8 & 12 & $5^{\prime} 00^{\prime \prime}$ \\
\hline 3 & Terminal Deorodo - Terminal Américo Fontenelle (Semi-Direto/ Direto) & 56.5 & 104 & 32.6 & 6 & $10^{\prime} 00^{\prime \prime}$ \\
\hline 4 & Terminal Deorodo - Terminal Presidente Vargas (Semi-Direto/ Direto) & 62.0 & 115 & 32.3 & 36 & $1^{\prime} 50^{\prime \prime}$ \\
\hline 5 & Terminal Margaridas - I.N.T.O. (Parador) & 32.8 & 72 & 27.3 & 60 & $1^{\prime} 00^{\prime \prime}$ \\
\hline 6 & Terminal Margaridas - Terminal Gasômetro (Semi-Direto/ Direto) & 35.6 & 70 & 30.5 & 12 & $5^{\prime} 00^{\prime \prime}$ \\
\hline 7 & Terminal Margaridas - Terminal Américo Fontenelle (Semi-Direto) & 40.6 & 80 & 30.5 & 5 & $12^{\prime} 00^{\prime \prime}$ \\
\hline 8 & Terminal Margaridas - Terminal Presidente Vargas (Semi-Direto/ Direto) & 46.1 & 90 & 30.7 & 30 & $2^{\prime} 00^{\prime \prime}$ \\
\hline 9 & Terminal Missões - I.N.T.O. (Parador) & 26.4 & 60 & 26.4 & 53 & $1^{\prime} 10^{\prime \prime}$ \\
\hline 10 & Terminal Missões - Terminal Gasômetro (Semi-Direto/ Direto) & 28.5 & 60 & 28.5 & 15 & $4^{\prime} 00^{\prime \prime}$ \\
\hline 11 & Terminal Missões - Terminal Américo Fontenelle (Semi-Direto) & 33.5 & 70 & 28.7 & 10 & $6^{\prime} 00^{\prime \prime}$ \\
\hline 12 & Terminal Missões - Terminal Presidente Vargas (Semi-Direto/ Direto) & 39.0 & 80 & 29.3 & 40 & $1 ' 30 "$ \\
\hline 13 & Terminal Fundão - Terminal Gasômetro (Parador) & 19.8 & 54 & 22.0 & 12 & $5^{\prime} 00^{\prime \prime}$ \\
\hline 14 & Terminal Fundão - Terminal Américo Fontenelle (Parador) & 24.8 & 64 & 23.3 & 11 & 5'30' \\
\hline 15 & Terminal Fundão - Terminal Presidente Vargas (Parador) & 30.8 & 78 & 23.7 & 25 & $2^{\prime} 25^{\prime \prime}$ \\
\hline 16 & Terminal Fundão - Terminal Presidente Vargas (Direto) & 30.8 & 72 & 25.7 & 4 & $15^{\prime} 00^{\prime \prime}$ \\
\hline 17 & Terminal Penha - I.N.T.O. (Parador) & 23.2 & 62 & 22.4 & 50 & 1'15" \\
\hline 18 & Terminal Penha - Terminal Gasômetro (Direto) & 25.2 & 64 & 23.6 & 8 & 7'30" \\
\hline 19 & Terminal Penha - Terminal Presidente Vargas (Direto) & 35.8 & 88 & 24.4 & 24 & $2^{\prime} 30^{\prime \prime}$ \\
\hline
\end{tabular}

Source: Logit (2014, p.44-45). * Values refer to both-way trip. 


\section{Statistical Annex ${ }^{3}$}

A statistical analysis provides a more robust analysis of how the potential accessibility gains of the TransBrasil BRT project will be distributed across the population from different income levels. A statistical regression model is used to test whether the difference in accessibility gains between people from different income groups is large enough to be considered statistically significant while controlling for confounding factors. A second motivation for such analysis is to verify if the assessment of the distributive effects of the new transport project is sensitive to the modifiable temporal unit problem (MTUP). The regression allows us to test whether choosing different time thresholds can lead to conclusions which are equally statistically significant despite being substantially different.

Previous studies have analyzed the distributional effects of transport policies using conventional statistical analysis (Fan et al., 2012; Foth et al., 2013). However, transport and land use processes are marked by spatial dependence, meaning that the accessibility levels of a location are related to its neighboring areas (Páez \& Scott, 2005). This spatial dependence in the data violates basic assumptions of standard regression analysis and leads to biased parameters and possibly flawed conclusions and policy prescriptions (Páez \& Scott, 2005). To take spatial dependence into account, this study uses a spatial regression model to estimate whether wealthier areas will benefit by the accessibility gains from the implementation of the TransBrasil corridor. Other variables influence where new transport infrastructure is likely to be built and consequently which locations derive higher accessibility gains from new investments. Areas with greater job and population densities, for example, are likely to have higher transport demand and make transport projects more economically viable (Kutz, 2003). Topography is another relevant variable that puts geographical barriers for construction and which has direct influence over construction costs and where surface transportation modes are likely to go (ibid.). In order to control for these factors, the regression model included information on local population and job densities as well as terrain elevation in the independent variables. The baseline model without spatial effects is written as:

\footnotetext{
${ }^{3}$ This annex is not included is only available in the preprint version of the manuscript.
} 
Where:

$$
\begin{gathered}
\log \left(\mathrm{R}_{i o}\right)=\beta_{0}+\beta_{1} \log \left(\mathrm{I}_{i}\right)+\beta_{2} \log \left(\mathrm{P}_{i}\right)+\beta_{3} \log \left(\mathrm{O}_{o i}\right)+\beta_{4} \log \left(\mathrm{E}_{i}\right)+\varepsilon_{i} \\
\mathrm{R}_{i o}=\frac{A_{i o T}^{S}}{A_{i o T}^{b}}
\end{gathered}
$$

$R_{i o}$ is the relative change in accessibility level from polygon $i$ to opportunities of type $o$ between baseline and scenario $s$ of partial or full operation;

$A_{i o T}^{\mathrm{S}}$ is the number of opportunities of type $o$ that could be accessed from origin $i$ under travel time threshold $T$ in scenario $s$ of partial or full operation;

$I_{i}$ is the average household income per capita in polygon $i$;

$P_{i}$ is the population density in polygon $i$;

$O_{i o}$ is the density of jobs in polygon $i$; and

$E_{i}$ is the average terrain elevation in meters of polygon $i$.

Variation in accessibility was measured as the ratio between accessibility levels with and without the new BRT. This approach means that changes in accessibility have proportionally lower impact in those areas that already had higher accessibility before the TransBrasil, in line with decreasing marginal returns. In other words, it implies that for a person living in an area with access to 100 jobs, an increase of, say, 50 jobs would add more to this person's utility than for a person who already had access to 1000 jobs.

The spatial dependence underlying the baseline model was evaluated using the Lagrange multiplier test, following standard methods used in the literature (Elhorst, 2010; LeSage, 2008). The Lagrange test indicated stronger preference for the spatial lag specification but also found the spatial lag and error models to be significant, which suggests that the spatial lag, Durbin or spatial autocorrelation (SAC) models could all be appropriate. Moving forward with a strategy of model determination, spatial Durbin model (SDM) was chosen because it gave the best results for the Akaike Information Criterion (AIC) and minimized and autocorrelation in the OLS residuals.

The SDM specification assumes there is spatial autocorrelation in the both dependent variable $y$ and explanatory variables $x$. This allows estimation of how strongly the accessibility gain in polygon $i$ is associated not only with the land use characteristics (including income) of $i$ but also with the land use characteristics and accessibility gains in the neighboring polygons of $i$. Because the Durbin model includes a spatial lag in both set of variables, it produces coefficient estimates that are unbiased even if one or more relevant explanatory variables are omitted from the regression equation (Elhorst, 2010; LeSage, 2008). This is an important advantage given that 
only a limited set of independent variables is considered in the current analysis (see above). Polygons were defined as neighbors if they share at least one boundary point using a standard queen contiguity matrix. ${ }^{4}$

\section{Regression Results}

While a simple visual analysis presented in section 6 suggests that most gains in access to jobs would accrue to poorer areas (shown in reddish colors), a more robust statistical analysis is necessary to test whether these differences are statistically significant and whether the results vary according to different travel-time thresholds or if they are robust to MTUP. Tables 2 and 3 report the total effects of the spatial Durbin regression model, measuring how household income per capita in 2010 is associated with the future changes in accessibility to jobs brought by the full and partial construction of the TransBrasil BRT. For both scenarios, regression results show a small but negative association between accessibility gains and income levels, suggesting that on average lower-income groups would have larger accessibility benefits from the new BRT than wealthier groups. Considering a threshold of 60 minutes under the full operation scenario, for example, the results indicate that a $1 \%$ increase in average household income per capita is associated with an approximate $0.047 \%$ smaller accessibility gain. To put this result into perspective, every additional U $\$ 100$ dollars in household income per capita (equivalent to $\mathrm{R} \$ 325$ Brazilian Reais, close to one-third of national minimum wage) is associated with a $1 \%$ smaller accessibility gain on average. According to the results in Tables 2 and 3, the total effects are consistently smaller in the partial than in the full operation scenario, which suggests that extending this BRT into the city center would make this project more progressive.

Although the direction of association between gains in accessibility and income level is consistently negative, the magnitude of this association varies considerably when using different cutoff time values. In the full operation scenario, for example, this effect is 3 times larger under the 30-minute threshold compared to 120 minutes (Table 3). The strength of the association between income and accessibility gains tends to decline for time thresholds longer than 60

\footnotetext{
${ }^{4}$ Various contiguity and spatial weight matrices were tested, including queen, rook, $K$-nearest neighbors (from 2 to 20), neighborhood contiguity with travel time thresholds (from 10 to 90 minutes every ten 10 minutes) and a weight matrix based on the inverse of travel times via public transport between polygons. The queen type of contiguity matrix captured the spatial dependence in the data most successfully, returning the highest value of Moran's $I$ test for spatial autocorrelation in the OLS residuals.
} 
minutes. This suggests that the TransBrasil BRT promotes greater accessibility gains for lowthan for high-income groups, particularly when shorter travel times are considered. It also indicates a transition from more progressive to neutral effects as longer travel times are considered. These results indicate more broadly that evaluations of the distributional effects of transport accessibility based on cumulative opportunity measures are sensitive to the timethreshold choice and that that the consideration of the modifiable temporal unit problem (MTUP) is integral to answering the questions of how large is the accessibility impact of a transport policy and how it is distributed.

Table 2. Total effects of spatial Durbin model showing association with gains in access to formal jobs given various travel time thresholds under full operation scenario of TransBrasil BRT.

\begin{tabular}{lllll}
\hline & 30 min. & 60 min. & 90 min. & 120 min. \\
\hline $\log$ (income) & $-0.014^{* * * *}$ & $-0.047^{* *}$ & $-0.016^{* * *}$ & -0.005 \\
& $(0.004)$ & $(0.016)$ & $(0.006)$ & $(0.003)$ \\
$\log$ (popdens) & $-0.007^{*}$ & $-0.024^{*}$ & $-0.011^{*}$ & 0.002 \\
& $(0.003)$ & $(0.011)$ & $(0.005)$ & $(0.002)$ \\
$\log$ (jobdens) & $0.007^{* * *}$ & $0.023^{* * *}$ & $0.010^{* * *}$ & 0.000 \\
& $(0.002)$ & $(0.006)$ & $(0.002)$ & $(0.001)$ \\
$\log ($ elevation) & $-0.008^{* *}$ & $-0.021^{*}$ & -0.005 & -0.000 \\
& $(0.003)$ & $(0.011)$ & $(0.004)$ & $(0.002)$ \\
rho & $0.739^{* * *}$ & $0.947^{* * *}$ & $0.891^{* * *}$ & $0.849^{* * *}$ \\
& $(0.013)$ & $(0.004)$ & $(0.007)$ & $(0.009)$ \\
\hline Pseudo R2 & 0.457 & 0.845 & 0.767 & 0.668 \\
Num. obs. & 3571 & 3580 & 3581 & 3581 \\
Parameters & 11 & 11 & 11 & 11 \\
Log Likelihood & 6047.286 & 5891.710 & 7463.830 & 9632.171 \\
AIC (Linear model) & -10094.363 & -5478.946 & -9851.494 & -15352.707 \\
AIC (Spatial model) & -12072.572 & -11761.421 & -14905.660 & -19242.343 \\
LR test: statistic & 1980.208 & 6284.475 & 5056.166 & 3891.636 \\
LR test: p-value & 0.000 & 0.000 & 0.000 & 0.000 \\
\hline
\end{tabular}

Notes: AIC $=$ Akaike information criterion; standard errors are in parentheses; $* * *=p<0.001, * *=p<0.01, *=p$ $<0.05$. 
Table 3. Total effects of spatial Durbin model showing association with gains in access to formal jobs given various travel time thresholds under partial operation scenario of TransBrasil BRT.

\begin{tabular}{lllll}
\hline & 30 min. & 60 min. & 90 min. & 120 min. \\
\hline $\log ($ income) & $-0.012^{* * *}$ & $-0.021^{* * *}$ & $-0.012^{* * * *}$ & $-0.007^{* * *}$ \\
& $(0.003)$ & $(0.005)$ & $(0.003)$ & $(0.002)$ \\
$\log$ (popdens) & $-0.005^{*}$ & -0.003 & -0.004 & $0.003^{*}$ \\
& $(0.002)$ & $(0.003)$ & $(0.002)$ & $(0.002)$ \\
$\log ($ jobdens) & $0.005^{* * *}$ & $0.007^{* * *}$ & $0.005^{* * *}$ & -0.000 \\
& $(0.001)$ & $(0.002)$ & $(0.001)$ & $(0.001)$ \\
$\log ($ elevation) & $-0.006^{*}$ & $-0.007^{*}$ & -0.000 & 0.001 \\
& $(0.002)$ & $(0.004)$ & $(0.002)$ & $(0.001)$ \\
rho & $0.759^{* * *}$ & $0.892^{* * *}$ & $0.893^{* * *}$ & $0.905^{* * *}$ \\
& $(0.012)$ & $(0.007)$ & $(0.007)$ & $(0.006)$ \\
\hline Pseudo R2 & 0.471 & 0.770 & 0.747 & 0.811 \\
Num. obs. & 3571 & 3580 & 3581 & 3581 \\
Parameters & 11 & 11 & 11 & 11 \\
Log Likelihood & 7145.605 & 8249.277 & 10118.013 & 11681.540 \\
AIC (Linear model) & -12202.389 & -11565.116 & -15555.503 & -17660.196 \\
AIC (Spatial model) & -14269.210 & -16476.554 & -20214.026 & -23341.081 \\
LR test: statistic & 2068.821 & 4913.438 & 4660.523 & 5682.884 \\
LR test: p-value & 0.000 & 0.000 & 0.000 & 0.000 \\
\hline
\end{tabular}

Notes: AIC $=$ Akaike information criterion; standard errors are in parentheses; $* * *=p<0.001, * *=p<0.01, *=p$ $<0.05$. 